\title{
Impaired D2 Dopamine Receptor Function in Mice Lacking Type 5 Adenylyl Cyclase
}

\author{
Ko-Woon Lee, ${ }^{1,2}$ Jang-Hee Hong, ${ }^{1,3}$ In Young Choi, ${ }^{1}$ Yongzhe Che, ${ }^{4}$ Ja-Kyeong Lee, ${ }^{4}$ Sung-Don Yang, ${ }^{5}$ \\ Chang-Woo Song, ${ }^{5}$ Ho Sung Kang, ${ }^{2}$ Jae-Heun Lee, ${ }^{3}$ Jai Sung Noh, ${ }^{6}$ Hee-Sup Shin, ${ }^{7}$ and Pyung-Lim Han ${ }^{1}$ \\ ${ }^{1}$ Department of Neuroscience and Ewha Institute of Neuroscience, Ewha Womans University School of Medicine, Seoul, \\ 110-783, Korea, 2Department of Molecular Biology, Pusan National University, Pusan, 609-735, Korea, ${ }^{3}$ Department of \\ Pharmacology, College of Medicine, Chungnam National University, Taejon, 301-747, Korea, ${ }^{4}$ Department of Anatomy, \\ Inha University School of Medicine, Inchon, 400-712, Korea, 5Toxicology Research Group, Korea Research Institute of \\ Chemistry and Technology, Taejon, 305-345, Korea, 'Department of Psychiatry, Ajou University School of Medicine, \\ Suwon, 442-721, Korea, and 7 National Creative Research Initiative Center for Calcium and Learning, Korea Institute of \\ Science and Technology, Seoul, 136-791, Korea
}

Dopamine receptor subtypes $D_{1}$ and $D_{2}$, and many other seven-transmembrane receptors including adenosine receptor $A_{2 A}$, are colocalized in striatum of brain. These receptors stimulate or inhibit adenylyl cyclases (ACs) to produce distinct physiological and pharmacological responses and interact with each other synergistically or antagonistically at various levels. The identity of the AC isoform that is coupled to each of these receptors, however, remains unknown. To investigate the in vivo role of the type 5 adenylyl cyclase (AC5), which is preferentially expressed in striatum, mice deficient for the AC5 gene were generated. The genetic ablation of the AC5 gene eliminated $>80 \%$ of forskolin-induced $A C$ activity and $85-90 \%$ of $A C$ activity stimulated by either $D_{1}$ or $A_{2 A}$ receptor agonists in striatum. However, $D_{1}$ - or $A_{2 A}$-specific pharmaco-behaviors were basically preserved, whereas the signal cascade from $D_{2}$ to $\mathrm{AC}$ was completely abolished in $A C 5^{-/-}$, and motor activity of $A C 5^{-1-}$ was not suppressed by treatment of cataleptic doses of the antipsychotic drugs haloperidol and sulpiride. Interestingly, both haloperidol and clozapine at low doses remarkably increased the locomotion of $A C 5^{-1-}$ in the open field test that was produced in part by a common mechanism that involved the increased activation of $D_{1}$ dopamine receptors. Together, these results suggest that AC5 is the principal AC integrating signals from multiple receptors including $D_{1}, D_{2}$, and $A_{2 A}$ in striatum and the cascade involving AC5 among diverse $D_{2}$ signaling pathways is essential for neuroleptic effects of antipsychotic drugs.

Key words: AC5; dopamine receptors; knock-out mice; antipsychotics; striatum; adenylyl cyclase; cAMP; adenosine receptors
Dopaminergic systems play central roles not only in movement behaviors and motivated behaviors but also in pathological states, including Parkinson's disease, drug addictions, and schizophrenia (Ebadi and Srinivasan, 1995; Missale et al., 1998). Neuroanatomical substrates underlying these physiological and pathological responses include the striatum, where dopamine receptors are highly enriched (Levey et al., 1993; Surmeier et al., 1996). Historically, all five dopamine receptor isoforms cloned in mammals have been envisioned to stimulate or inhibit adenylyl cyclase (AC) to generate their physiological and pharmacological responses. After activation, $\mathrm{D}_{1}$-type dopamine receptors $\left(\mathrm{D}_{1}\right.$ and $\left.D_{5}\right)$ stimulate $A C$, whereas $D_{2}$-type dopamine receptors $\left(D_{2}, D_{3}\right.$, and $\mathrm{D}_{4}$ ) inhibit AC (Creese et al., 1983; Missale et al., 1998; Sidhu and Niznik, 2000). Despite the long history of dopamine receptor biology, the identity of the AC subtype that is coupled to specific dopamine receptor isoforms in the brain has not been verified.

To date, more than 10 different types of ACs, including cyto-

\footnotetext{
Received Feb. 8, 2002; revised June 19, 2002; accepted July 11, 2002.

This work was supported by the Neurobiology Research Program of the Korea Ministry of Science and Technology (KMOST) (J.-K.L., P.-L.H.) and partly by the Creative Research Initiative Program from KMOST (H.-S.S.). We thank K.-H. Lim and A.-L. Youn for their excellent help in behavioral works.

Correspondence should be addressed to Pyung-Lim Han, Ewha Institute of Neuroscience, Ewha Womans University School of Medicine, 70 Jongno-6-Ga, Jongno-Gu, Seoul, 110-783, Korea. E-mail: plhan@ewha.ac.kr.

Copyright (ㄷ) 2002 Society for Neuroscience 0270-6474/02/227931-10\$15.00/0
}

solic AC, have been cloned and characterized in mammals (Buck et al., 1999; Hanoune and Defer, 2001). Studies on the expression of ACs showed that many AC isoforms were expressed at various levels in striatum (Glatt and Snyder, 1993; Cali et al., 1994; Mons and Cooper, 1994; Lane-Ladd et al., 1997; Matsuoka et al., 1997; Antoni et al., 1998; Liu et al., 1998; Mons et al., 1998). The type 5 adenylyl cyclase (AC5) has been thought to be a component of dopamine receptor signaling, primarily because it was highly concentrated in striatum where $\mathrm{D}_{1}$ and $\mathrm{D}_{2}$ were expressed abundantly (Glatt and Snyder, 1993; Matsuoka et al., 1997). Unfortunately, further progress in understanding the in vivo role of ACs, including AC5, in dopamine receptor biology has been hampered by the lack of AC subtype-specific inhibitors.

The $\mathrm{A}_{2 \mathrm{~A}}$ receptors are highly concentrated in striatum, particularly in GABAergic striatopallidal neurons where $A_{2 A}$ and $D_{2}$ receptors are colocalized (Fink et al., 1992; Augood and Emson, 1994). Antagonistic interactions between $A_{2 A}$ and $D_{2}$ receptors in the basal ganglia system have been proposed to play a key role in the motor depressant effects of adenosine receptor agonists and the motor stimulant effects of adenosine receptor antagonists, such as caffeine (Ferre et al., 1997). In addition, many other seventransmembrane receptors, including opioid receptors and muscarinic acetylcholine receptors, are also highly concentrated in striatum. These receptors use AC as their effector and interact with dopaminergic systems synergistically or antagonistically at various 
levels (Gomeza et al., 1999; Jang et al., 2000). However, the integrity of the effector system of these receptors in vivo is basically undetermined.

One strategy to dissect the functional receptor-effector system is to create mice lacking an effector candidate and to examine the signaling pathway of receptors of interests with the mutant animals. Therefore, the current study was undertaken to unravel the interaction of AC5 with dopamine receptors and other receptors in striatum using AC5-deficient mice. We demonstrated that AC5 interacted with many receptors including dopamine receptors; consequently it acted as an effector of integrating signals from multiple receptors.

\section{MATERIALS AND METHODS}

AC5 knock-out cassette, homologous recombination of the AC5 gene, and genetics. The N-terminal 369 bp cDNA fragment of the rat AC5 (GenBank accession no. M96159) (Premont et al., 1992) was amplified by PCR using two primers, 5'-GTCGAGGAAAAGGCCGAGCGGCCGAGG-3' and 5'-CAGCCATGATAAGGATCACGCCCACAG-3'. The fragment was used to screen for mouse $A C 5$ genomic DNA clones from a mouse $129 \mathrm{SVJ}$ genomic DNA library (Stratagene). Two overlapping phage clones were isolated and characterized to contain the $1.3 \mathrm{~kb}$ ApaI fragment that covered the first half of predicted mouse AC5. The genomic DNA sequences around the $1.3 \mathrm{~kb} A p a \mathrm{I}$ fragment were determined, and an exon identified in the fragment was designated as exon 2. A part of the $A C 5$ sequences was deposited into GenBank (AF417936). The targeting cassette was constructed by subcloning the $2.2 \mathrm{~kb}$ short-arm (Bam HI-exon 2) and the $5.3 \mathrm{~kb}$ long-arm (ApaI-XhoI) at each side of pGK-neo and TK in front of the short-arm as depicted in Figure $1 A$. The pGK-neo clones were provided by P. Soriano (Fred Hutchison Cancer Research Center, Seattle, WA) and D. S. Lim (Korea University, Seoul, Korea). ES cell culture and embryo handlings were conducted by following a standard procedure (Joyner, 1993; Kim et al., 1997). Briefly, J1 embryonic stem (ES) cells were used for homologous recombination, and seven independent chimeric mice were generated. They were bred to $\mathrm{C} 57 \mathrm{BL} / 6 \mathrm{~J}$ mice to obtain heterozygote $\mathrm{F} 1$ mice. Intercrossing between heterozygote F1 produced F2 hybrids of homozygote $\left(A C 5^{-1-}\right)$, heterozygote $\left(A C 5^{+/-}\right)$, and wild-type $\left(A C 5^{+/+}\right)$littermates, which were used in this study.

Northern, Southern, and Western blot analyses. Northern blot analysis was performed as described (Kim et al., 1999). Briefly, membrane blot carrying $30 \mu \mathrm{g}$ of total RNA in each lane was prepared and hybridized with ${ }^{32}$ P-labeled probes prepared from the PCR-amplified 529 bp fragment (4232-4760) of the $3^{\prime}$-end of rat AC5 cDNA (Premont et al., 1992). For genomic Southern blots, a blot carrying $X b a \mathrm{I}$-digested genomic DNA was hybridized with the ${ }^{32} \mathrm{P}$-labeled $0.5 \mathrm{~kb}$ SalI-HindIII fragment as indicated (see Fig. $1 A$ ). A PCR method was also used in genotyping. The PCR primers were AC5-(A), 5'-ACCGTCGAGGATGGAGACGG-3' (971-990); AC5-(A+), 5'-GTGGCTGTGGCAGC AACAGG-3' (13831402); and AC5-(pGK2r), 5'-CAGCGCGGCAGACGTGCGCT-3'. The PCR using the $(A)$ and $(A+)$ or $(A)$ and $(p G K 2 r)$ combination generates $432 \mathrm{bp}$ of wild-type allele and $665 \mathrm{bp}$ of mutant allele, respectively. For Western blot analyses, primary antibodies for PKA $\mathrm{C}_{\alpha}$ (Santa Cruz Biotechnology), PKA RI (Transduction Laboratories), PKA RII (Santa $_{\alpha}$ Cruz Biotechnology), $\mathrm{G}_{\mathrm{s} \alpha}, \mathrm{G}_{\mathrm{i} \alpha}, \mathrm{G}_{\mathrm{o} \alpha}$, and $\mathrm{G}_{\mathrm{z} \alpha}$ (Santa Cruz Biotechnology) were purchased.

Histological examinations. Tissue sections for immunohistochemical staining, receptor binding study, or hematoxylin-eosin staining were prepared as described (Kim et al., 1999; Lee et al., 1999). Briefly, brain, heart, or kidney sections cut at $40 \mu \mathrm{m}$ by vibratome, at $14 \mu \mathrm{m}$ by cryostat, or at $4 \mu \mathrm{m}$ by microtome after embedding with paraffin were fixed in $4 \%$ paraformaldehyde for $15 \mathrm{~min}$ and placed for histological study. Animals were handled in accordance with the guideline of animal care at Ewha Womans University School of Medicine. The polyclonal anti-AC5 antibody was purchased from Santa Cruz Biotechnology. Primary antibodies for substance $\mathrm{P}$ (Chemicon), dynorphin (Oncogene), neuropeptide Y (Chemicon), enkephalin (Chemicon), tyrosine hydroxylase (Chemicon), GAD (Chemicon), and parvalbumin (Santa Cruz Biotechnology) were purchased.

$A C$ assay. Striatum, frontal cortex of cerebrum, and cerebellum of adult brain were excised and subjected to AC assays. In preparations of the striatum, the dorsal striatum (caudate and putamen) and ventral striatum (the nucleus accumbens and its surrounding regions) were included unless indicated otherwise. In preparations of the frontal cortex, we included most cortical regions of the frontal lobe but excluded olfactory bulbs, striatum, thalamus, and the cortical regions posterior to the motor and sensory cortices. In preparations of the cerebellum, anterior and posterior lobes were included.

AC assay was performed as described (Onali et al., 1985; Olianas et al., 1997) with a modification using ${ }^{125}$ I-cAMP and anti-cAMP antibody (Amersham Biosciences). Prepared brain tissues were homogenized separately using a Teflon/glass homogenizer in $10 \mathrm{~mm}$ imidazole, $\mathrm{pH} 7.3,2$ mm EDTA, and 10\% sucrose. After tissue debris was spun down at 1000 $\mathrm{rpm}(23 \times g)$, crude membrane fractions were prepared by centrifugation at $25,000 \times \mathrm{g}$ at $4^{\circ} \mathrm{C}$ for $30 \mathrm{~min}$ and suspended in $10 \mathrm{~mm}$ imidazole or 10 $\mathrm{mm}$ Tris- $\mathrm{HCl}$ (for $\mathrm{D}_{2}$ assay) to a final concentration of $2-3 \mu \mathrm{g} / \mu \mathrm{l}$. The resulting membrane samples were aliquoted in 25-30 $\mu \mathrm{l}$ volume and stored at $-70^{\circ} \mathrm{C}$ until use. For each AC reaction, $20 \mu \mathrm{g}$ of total protein was used. All reactions below were prepared in $0.1 \mathrm{ml}$ volume, and membrane samples were added last.

The forskolin-induced AC activation was produced in $100 \mathrm{~mm}$ HEPES, pH 7.4, $100 \mathrm{~mm} \mathrm{NaCl,} 4 \mathrm{~mm} \mathrm{MgCl}_{2}, 2 \mathrm{~mm}$ EDTA, $0.5 \mathrm{~mm}$ 3-isobutyl-1-methylxantine (IBMX), $2 \mathrm{mM}$ ATP, $20 \mathrm{mM}$ phosphocreatine, and $5 \mathrm{U}$ of creatine phosphokinase with $10 \mu \mathrm{M}$ forskolin at $30^{\circ} \mathrm{C}$ for $15 \mathrm{~min}$ in vitro.

For $\mathrm{D}_{1}$ and $\mathrm{A}_{2 \mathrm{~A}}$ activation assays, reactions were performed in $10 \mathrm{~mm}$ imidazole, pH 7.3, 0.5 mM $\mathrm{MgCl}_{2}, 0.5 \mathrm{~mm}$ IBMX, 0.2 mM EGTA, $0.5 \mathrm{~mm}$ DTT, $0.01 \mathrm{~mm}$ pargyline, $1 \mu \mathrm{M}$ GTP, $2 \mathrm{~mm}$ ATP, $20 \mathrm{~mm}$ phosphocreatine, and $5 \mathrm{U}$ of creatine phosphokinase at $30^{\circ} \mathrm{C}$ for $15 \mathrm{~min}$ in vitro.

For the $\mathrm{D}_{2}$ activation assay, reactions were incubated in $80 \mathrm{~mm}$ Tris/ $\mathrm{HCl}, \mathrm{pH} 7.4,2 \mathrm{~mm} \mathrm{MgSO}_{4}, 1 \mathrm{~mm}$ EGTA, $150 \mathrm{~mm} \mathrm{NaCl}, 0.5 \mathrm{~mm}$ IBMX, $0.5 \mathrm{~mm}$ DTT, $0.05 \mathrm{~mm}$ GTP, and $0.2 \mathrm{~mm}$ ATP at $30^{\circ} \mathrm{C}$ for $5 \mathrm{~min}$ in vitro. For the muscarinic acetylcholine receptor assay, reactions were made in $80 \mathrm{~mm}$ Tris/ $\mathrm{HCl}$, pH 7.4, 2 mu $\mathrm{MgCl}_{2}, 0.3 \mathrm{~mm}$ EGTA, 1 mм DTT, 0.5 $\mathrm{mM}$ IBMX, $0.1 \mathrm{mM}$ GTP, and $0.2 \mathrm{~mm} \mathrm{ATP}$ at $30^{\circ} \mathrm{C}$ for $5 \mathrm{~min}$ in vitro.

Reactions were terminated by adding $0.5 \mathrm{ml}$ of $0.1 \mathrm{~N} \mathrm{HCl}$ and centrifuged at $22,000 \times g$ for $5 \mathrm{~min}$, and supernatant was taken. The amount of cAMP formed was determined by the ${ }^{125} \mathrm{I}$-cAMP assay system (Amersham Biosciences). The assay was based on the competition between unlabeled cAMP and a fixed quantity of ${ }^{125} \mathrm{I}$-cAMP and anti-cAMP antibody. According to the manufacturer's instructions, higher assay sensitivity was obtained by acetylation of protein samples. Three microliters of the reaction sample were mixed with $100 \mu \mathrm{l}$ of $0.05 \mathrm{M}$ acetate buffer, pH 5.8. After adding $8 \mu \mathrm{l}$ of the mix of 1 vol of acetic anhydride and 2 vol of triethylamine, reactions were vortexed vigorously for 7-8 min. Twenty microliters of acetylated sample were mixed with $80 \mu \mathrm{l}$ of assay buffer ( $0.05 \mathrm{M}$ acetate buffer, pH 5.8), followed by adding $100 \mu \mathrm{l}$ of anti-cAMP antibody. After incubation at $4^{\circ} \mathrm{C}$ for $3 \mathrm{hr}$, they were added with $100 \mu \mathrm{l}$ of ${ }^{125} \mathrm{I}$-cAMP $(30,000 \mathrm{cpm} / \mathrm{ml})$ and incubated further at $4^{\circ} \mathrm{C}$ overnight. Then they were mixed with $500 \mu \mathrm{l}$ of Amerlex-M secondary antibody conjugated with magnetic beads and incubated at room temperature for $15 \mathrm{~min}$. After centrifugation at $3000 \times g$ for $10 \mathrm{~min}$, pellet was used to determine the bound radioactivity by Packard gamma counter. The radioactivity was converted to picomoles of cAMP by comparison to the reference curve that was constructed with standards. $\mathrm{AC}$ activities were presented by averaging three to six independent measurements with duplicates, for which protein samples were taken from more than three animals for each genotype.

Molecular cloning ACs present in the striatum of $\mathrm{AC}^{-1-}$. To identify $\mathrm{AC}$ responsible for the AC activity in the striatum of $A C 5^{-/-}$, RT-PCR analyses were performed using a battery of primer sets: 5'-GACATTGTGGGCTTCAC-3' and 5'-CTTCAGTAGCCTCAGCC-3' for AC1, 5' -CCTCGACACACTCTGGACGG-3' and 5'-GCTGGCAGTGCAGTAGCTC for AC2, 5'-GATGCAGCTGCTGAGGGAG-3' and 5'-CAGTCTTGGTCTTCTCCCGC for AC3, 5'-GGATTGCTGTCTTCTCTGG-3' and 5'-GTAGGTGATGATCAGAGCTG-3' for AC4, 5'-ACCGTCGAGGATGGAGACGG-3' and 5'-GTGGCTGTGGCAGCAACAGGC-3' for AC5, 5'-CCTGATACTCGGGATTTATG-3' and 5'-CCACAGCTGGGCAGTCCAG-3' for AC6, 5'-CAACATTGAATCACCTGGAC-3' and 5'-GATGGCCTGGAGTGTACTTC-3' for AC7, and 5'-CCGGCCTGGGCACATCTTTG-3' and 5'-CGGCGGGGCTCAGGCAGTC-3' for AC8. Undesired amplification of genomic DNA in RT-PCR was monitored by using total RNA as template. The partial sequences of mouse AC3 cDNA clone was deposited in GenBank (AF253540).

$D_{1}$ and $D_{2}$ dopamine receptor binding assays. Striatum was homogenized using a Teflon/glass homogenizer in $10 \mathrm{~mm}$ Tris $\cdot \mathrm{HCl}, \mathrm{pH} 7.4$, and crude membrane fractions were prepared. Receptor-ligand binding experiments were performed using ${ }^{3} \mathrm{H}-\mathrm{SCH} 23390$ or ${ }^{3} \mathrm{H}$-spiperone for $\mathrm{D}_{1}$ and 
$\mathrm{D}_{2}$ receptors, respectively. Cold SCH23390 or butaclamol was used for blocking of nonspecific binding. Binding reactions were performed for 1 $\mathrm{hr}$ at room temperature. For the ${ }^{125}$ I-sulpiride binding study, brain sections mounted on a glass slide were overlaid with ligand binding buffer (50 mM HEPES, pH 7.5, 1 mM EDTA, and 0.1\% BSA) containing $0.5 \mathrm{~nm}$ ${ }^{125} \mathrm{I}$-sulpiride $(2000 \mathrm{Ci} / \mathrm{mmol})$. Nonspecific binding was blocked with cold sulpiride. After incubation at room temperature for $60 \mathrm{~min}$, the slides were washed with ice-cold ligand binding buffer and ice-cold water, air dried, and autoradiographed.

Behavioral assessments. For the open field test, mice (10-20 weeks) were placed individually in a test chamber and monitored on a TV screen after video recording. A test chamber consisted of a $60 \times 60 \mathrm{~cm}^{2}$ floor with $40-\mathrm{cm}$-high walls in which the floor was marked by lines to have 25 equal squares. Animals were allowed to spend $15 \mathrm{~min}$ in the chamber for acclimation. At the end of acclimation, each drug dissolved in $120 \mu \mathrm{l}$ of $0.9 \%$ saline was administered intraperitoneally. SKF38393, SCH23390, CGS21680, quinpirole, oxotremorine, haloperidol, clozapine, sulpiride, and dihydrexidine were purchased from Tocris. Horizontal locomotor activity was judged by cumulative counts of line crossovers of animals for a $60 \mathrm{~min}$ period (15-75 min). Later, we established a computerized video tracking system that was used to obtain the data for the open field system in Figures $3 D, 4 D$, and $8 A, B$. For this system, we used a test chamber consisting of a $45 \times 45 \mathrm{~cm}^{2}$ floor with 40 -cm-high walls. Horizontal locomotor activity was judged by the distance of the animal's movement for $60 \mathrm{~min}$ after drug administration. In all experiments, mice that were administered drugs were not used further. For behavioral assessments, $n=4-9$ for each genotype, unless indicated otherwise.

Catalepsy was measured by a bar test with a cutoff time of $3 \mathrm{~min}$. The forepaws of the mice were placed on a 1-cm-diameter bar held $5 \mathrm{~cm}$ above the floor and $5 \mathrm{~cm}$ from the front wall, and the time spent in the given posture was regarded as an indication of catalepsy.

Statistical analysis. Two-sample comparison was performed using Student's $t$ test, and multiple comparisons were made using one-way ANOVA followed by the Newman-Keuls multiple range test. All data were presented as the mean \pm SEM, and a statistical difference was accepted at $5 \%$ level unless indicated otherwise.

\section{RESULTS}

\section{Generation of $A C 5$ knock-out mice}

To elucidate the in vivo role of AC5, we generated mice deficient for the $A C 5$ by means of homologous recombination (Fig. $1 A, B$ ). Homozygous males and females were viable and healthy. Northern analysis revealed that the $A C 5$ expression was totally abolished in the striatum of $A C 5^{-1-}$ mice (Fig. $1 C$ ). In agreement with these data, anti-AC5 immunoreactivity was absent in the brain of $A C 5^{-/-}$mice (Fig. $1 D$ ).

\section{Viability and development of $A C 5^{-1-}$ mutant animals}

The numbers of homozygotes, heterozygotes, and wild-type littermates were 97 (23.7\%), $210(51.2 \%)$, and 103 (25.1\%), respectively, among the first 410 progenies generated from F1 intercrosses. There was no sex bias in F2 offspring. Both homozygous males and females were fertile and bred normally. The $A C 5^{-1-}$ mice were active in their home cage and morphologically indistinguishable from their wild-type littermates. Body weight was slightly reduced to $90-95 \%$ of that of $A C 5^{+/+}$during the first 20 weeks after birth (data not shown). AC5 has been thought to be an important component in the function of heart and kidney during development and in adult life (Chabardes et al., 1999; Hanoune and Defer, 2001). Histological examination, however, revealed no obvious difference between $A C 5^{-/-}$and wild-type littermates in most respects, including the sizes and microscopic structures of heart and kidney (data not shown). Together, these results indicate that although the absence of the $A C 5$ gene results in slightly delayed growth after birth, the $A C 5$ is not essential for survival in mice.
A

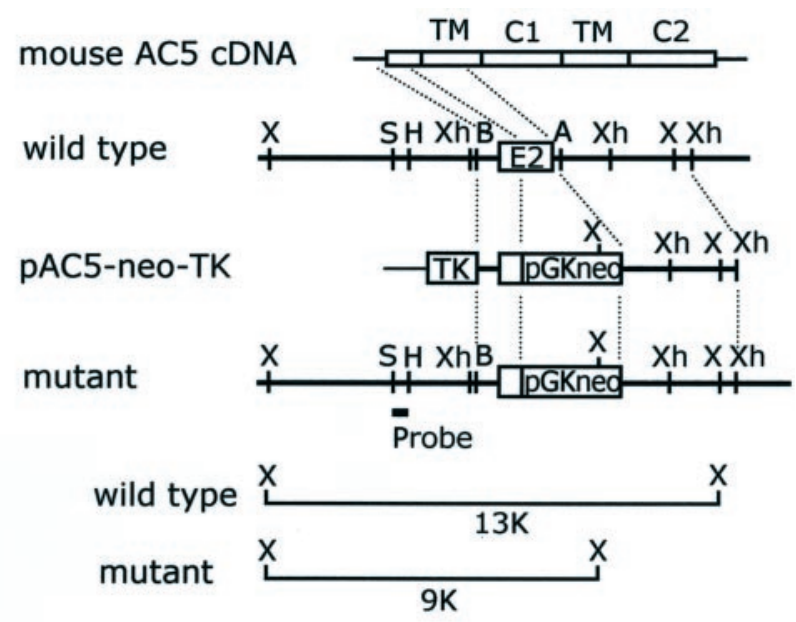

\section{B}
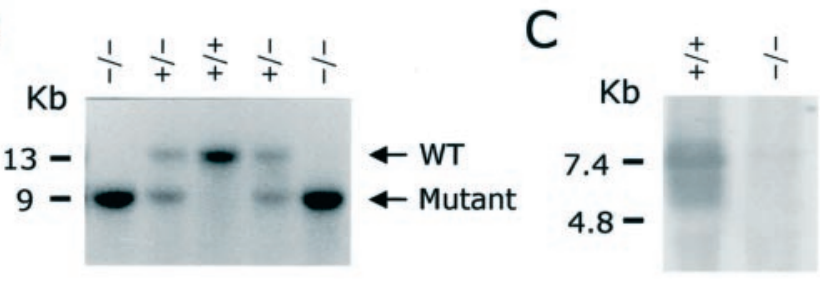

D
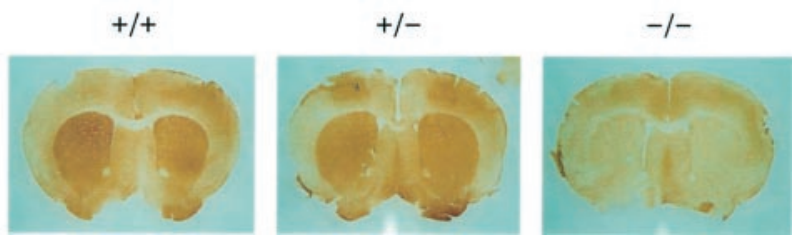

Figure 1. Targeted disruption of the $A C 5$ gene locus. $A$, Restriction map of $129 \mathrm{SVJ}$ genomic DNA clone (wild type), targeting cassette ( $p A C 5$-neo$T K$ ), and homologous recombinant (mutant). The $1.3 \mathrm{~kb}$ ApaI fragment in wild type carried an exon covering most of the first half of AC5. Predicted mouse AC5 cDNA at the top was drawn on the basis of the published rat cDNA sequence, in which $T M$ indicates the transmembrane domains and $C 1$ and $C 2$ represent the catalytic domains located in the cytoplasmic side.

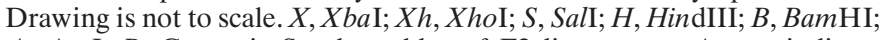
A, ApaI. B, Genomic Southern blot of F2 littermates. Arrows indicate wild-type $(13 \mathrm{~kb})$ and mutant $(9 \mathrm{~kb})$ bands on the $X b a$ I-digested genomic DNA blot. $C$, Northern blot analysis shows no $A C 5$ messages in the striatum of $A C 5^{-1-}$. The sizes of AC5 message were $\sim 6$ and $7.4 \mathrm{~kb} . D$, Immunohistochemical detection of AC5 expression in brain sections. Anti-AC5 antibody detected a background level of immunoreactivity in the brain of $A C 5^{-1-}$.

\section{Impairment of adenylyl cyclase activity in the brain of $\mathrm{AC5}^{-1-}$ mice}

To assess the AC activity abolished by the mutation of the $A C 5$, we compared AC activity in the brain of mutant animals with that of wild-type littermates. In the striatum, the baseline AC activity of $A C 5^{-1-}$ in the absence of exogenous activators was slightly reduced when compared with that of $A C 5^{+/+}$. However, forskolin $(10 \mu \mathrm{M})$ treatment enhanced AC activity $>20$-fold in $A C 5^{-1-}$, which reached $18 \%$ of that in $A C 5^{+/+}$(Fig. 2A). Other AC subtypes present in the striatum of $A C 5^{-1-}$, for which we identified AC1 through AC8, the expression of which was not altered as determined by semiquantitative RT-PCR analyses (data not shown), may account for the forskolin-induced AC activity in $A C 5^{-1-}$. In the frontal cortex of cerebrum and in the cerebellum, the forskolin $(10 \mu \mathrm{M})$-enhanced AC activity in $A C 5^{-1-}$ was di- 


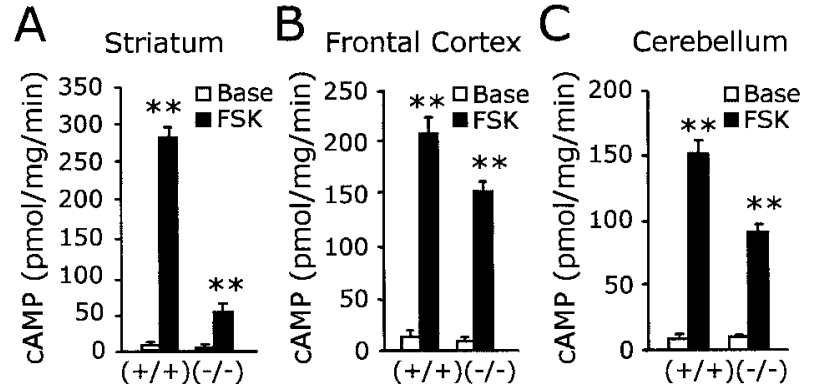

Figure 2. Impairment of AC activity in $A C 5^{-1-}$ mice. The forskolin (10 $\mu \mathrm{M})$-stimulated $\mathrm{AC}$ activity in $A C 5^{-/-}$was reduced to $18 \%$ in the striatum $(A), 73 \%$ in the cerebral cortex $(B)$, and $60 \%$ in the cerebellum $(C)$ of that in $A C 5^{+/+}$. The baseline AC activity in $A C 5^{-1-}$ was slightly reduced when compared with that of $A C 5^{+/+}(p<0.05)$. ** indicates a difference between two groups $(p<0.01)$. Base, Baseline; FSK, forskolin.

minished to 73 and $60 \%$, respectively, of that in wild-type littermates (Fig. 2B,C). Overall, these results suggest that AC5 is the major $\mathrm{AC}$ in the striatum, whereas it constitutes a minor $\mathrm{AC}$ in the frontal cortex and cerebellum of normal mice.

\section{General motor behaviors of naïve mutant animals}

We examined whether the genetic ablation of the $A C 5$ gene with the concomitant abolishment of the AC5 activity in the brain could produce any abnormality in the expression of motor behaviors. Regarding spontaneous motor activities including walking, running, climbing, grasping, writhing, and motor skills related to eating, $A C 5^{-1-}$ mice were indistinguishable from their wild-type littermates. $A C 5^{-1-}$ animals displayed no overt sign of ataxia or tremor, despite the fact that the forskolin-stimulated AC activity in the cerebellum was reduced to $60 \%$ of that in $A C 5^{+/+}$(Fig. $2 C$ ). Thus, spontaneous general motor activities of $A C 5^{-/-}$appeared to be normal.

\section{Coupling of $\mathrm{D}_{1}$ dopamine receptors and AC5}

The genetic disruption of the $A C 5$ and the presence of the forskolin-activated residual AC activity in the striatum of $A C 5^{-1-}$ prompted us to examine the receptor-effector interactions in the context of AC5. To delineate the interactions, we relied on biochemical and pharmaco-behavioral assay methods. First of all, we explored whether AC5 is the essential component downstream of $\mathrm{D}_{1}$ dopamine receptor activation. In the striatum of $A C 5^{+/+}$, the $\mathrm{D}_{1}$ agonist SKF38393 $(100 \mu \mathrm{M})$-stimulated AC activity was increased markedly $(29.04 \pm 2.04 \rightarrow 53.16 \pm 4.24$ pmol of cAMP per milligram per minute; $p<0.01 ; 183 \%$ of the baseline). Similarly, the AC activity stimulated by dihydrexidine (DHX; 100 $\mu \mathrm{M})$, a full agonist for $\mathrm{D}_{1}$, was enhanced more than twofold in $A C 5^{+/+}(29.04 \pm 2.04 \rightarrow 60.84 \pm 5.69$ pmol of cAMP per milligram per minute; $p<0.01 ; 210 \%$ of the baseline). In the striatum of $A C 5^{-/-}$, the SKF38393 $(100 \mu \mathrm{M})$-stimulated AC activity was increased at a low level, but it was consistently higher than the baseline control in repeated experiments $(5.05 \pm 0.16 \rightarrow$ $5.73 \pm 0.15$ pmol of cAMP per milligram per minute; $p<0.01$; $113 \%$ of the baseline). Consistently, the treatment with DHX $(100 \mu \mathrm{M})$ produced a comparable level of increase in $A C 5^{-1-}$ $(5.05 \pm 0.16 \rightarrow 5.80 \pm 0.21$ pmol of cAMP per milligram per minute; $p<0.01 ; 115 \%$ of the baseline), implying that a functional $\mathrm{D}_{1}-\mathrm{G}_{\alpha \mathrm{s}}-\mathrm{AC}$ system was present in the striatum of $A C 5^{-/-}$ (Fig. $3 A$ ). Overall, however, the increase of SKF38393- or DHXstimulated AC activity in $A C 5^{-1-}$ was reduced to $10-11 \%$ of that in $A C 5^{+/+}$. We assessed separately the DHX-stimulated AC activity in the dorsal (caudate and putamen) and ventral (nucleus accumbens and its surrounding areas) striatum and found no difference in their activation folds in these subdivisions of striatum (data not shown). Together, these results suggest that $D_{1}$ receptors use AC5 as their primary AC and other ACs as their alternative pathway. In the frontal cortex of cerebrum in $\mathrm{AC}^{+/+}$, where $D_{1}$ receptor density is not as high as in striatum, we observed that the DHX $(100 \mu \mathrm{M})$-stimulated AC activity was relatively low but substantially increased when compared with the baseline control $(10.75 \pm 0.26 \rightarrow 14.27 \pm 0.73$ pmol of cAMP per milligram per minute; $p<0.01 ; 133 \%$ of the baseline). In $A C 5^{-1-}$, the DHX-stimulated AC activity was also enhanced in a similar fold $(7.91 \pm 0.24 \rightarrow 10.87 \pm 0.29$ pmol of cAMP per milligram per minute; $p<0.01 ; 137 \%$ of the baseline), despite the fact that overall the DHX-stimulated AC activity in $A C 5^{-1-}$ was decreased to $73 \%$ of that in $A C 5^{+/+}$. Thus, other ACs available in the frontal cortex appear to interact effectively with $\mathrm{D}_{1}$.

We questioned whether the severe but incomplete loss of the $\mathrm{D}_{1}$ agonist-stimulated $\mathrm{AC}$ activity in the striatum of $A C 5^{-/-}$ would result in any impaired pharmaco-behaviors in response to $\mathrm{D}_{1}$ agonists or antagonists. To address this, we relied on a behavioral assay paradigm using the open field test. The open field test has been used widely for the measurement of neuronal outputs of the basal ganglia system responding to agonists and antagonists of dopamine receptors, psychomotor stimulants, or antipsychotic drugs (Xu et al., 1994; Dulawa et al., 1999). Administration of the $D_{1}$ agonist, SKF38393 (50 mg/ $\mathrm{kg}$, i.p.), induced an increase of the horizontal locomotor activity in wild-type littermates as reported previously (Gomeza et al., 1999). In $A C 5^{-1-}$, the same dose of SKF38393 produced a robust enhancement of the locomotion. Interestingly, the increase in the locomotor effects of the D1 agonist in $A C 5^{-1-}$ animals was higher than that observed in $A C 5^{+/+}$(Fig. $3 B, E$ ). Similar results were obtained by the administration of the $D_{1}$-specific agonist, DHX $(30 \mathrm{mg} / \mathrm{kg}$, i.p.) (Fig. 3D). In addition, the locomotor activity in the open field test after administration of the $\mathrm{D}_{1}$ antagonist, SCH23390 (0.3 $\mathrm{mg} / \mathrm{kg}$, i.p.), was fully suppressed in $A C 5^{-/-}$as seen in $A C 5^{+/+}$ (Fig. $3 C, F)$. Therefore, the $\mathrm{D}_{1}$ system in $A C 5^{-1-}$ appeared to be functional, at least in part, at the behavioral level, despite the fact that the $\mathrm{AC}$ activity induced by $\mathrm{D}_{1}$ stimulation was diminished severely. The identity of the non-AC5 effector(s) responsible for the observed $\mathrm{D}_{1}$-dependent pharmaco-behavioral responses was not known in the present study.

\section{Coupling of $\mathrm{A}_{2 \mathrm{~A}}$ adenosine receptor and $\mathrm{AC5}$}

Similar to those of $D_{1}$ dopamine receptors, $A_{2 A}$ receptors are preferentially expressed in the striatum and positively coupled to AC (Ferre et al., 1997; Moreau and Huber, 1999). We tested whether the anatomical and biochemical analogy between $\mathrm{A}_{2 \mathrm{~A}}$ and $\mathrm{D}_{1}$ receptors can be extended to the receptor-effector coupling mode. Biochemical assessment indicated that the $\mathrm{A}_{2 \mathrm{~A}}$ agonist CGS21680 $(10 \mu \mathrm{M})$-stimulated AC activity in the striatum of $A C 5^{+/+}$was highly increased $(26.14 \pm 2.51 \rightarrow 46.51 \pm 6.36 \mathrm{pmol}$ of cAMP per milligram per minute; $p<0.05 ; 178 \%$ of the baseline). In the striatum of $A C 5^{-1-}$, the AC activity stimulated by CGS21680 was significantly increased $(4.94 \pm 0.17 \rightarrow 7.34 \pm$ 0.52 pmol of cAMP per milligram per minute; $p<0.01 ; 149 \%$ of the baseline), suggesting the existence of a functional $\mathrm{A}_{2 \mathrm{~A}} / \mathrm{AC}$ system in the striatum of $A C 5^{-1-}$ (Fig. $4 A$ ). However, the $\mathrm{AC}$ activity stimulated by CGS21680 $(10 \mu \mathrm{M})$ in $A C 5^{-1-}$ was reduced to $16 \%$ of that in $A C 5^{+/+}$, indicating that $\mathrm{AC} 5$ was the major $\mathrm{AC}$ for $\mathrm{A}_{2 \mathrm{~A}}$ receptors. 
A
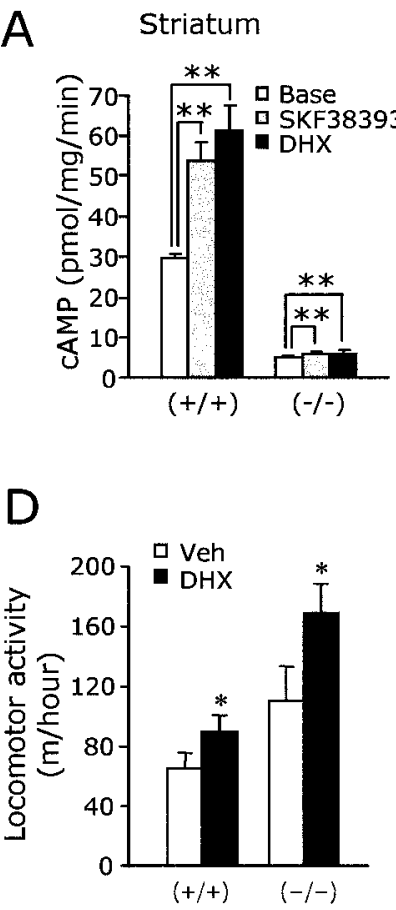

B

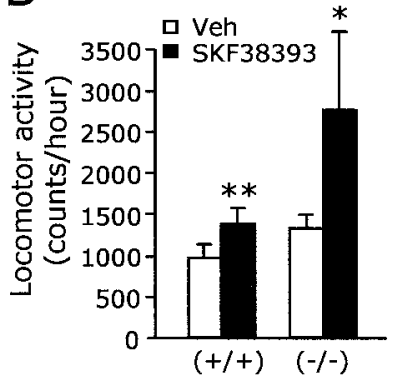

E

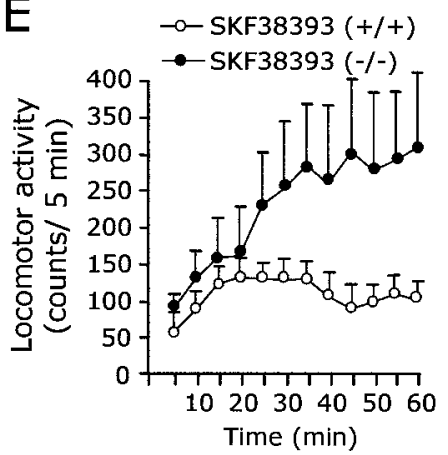

C
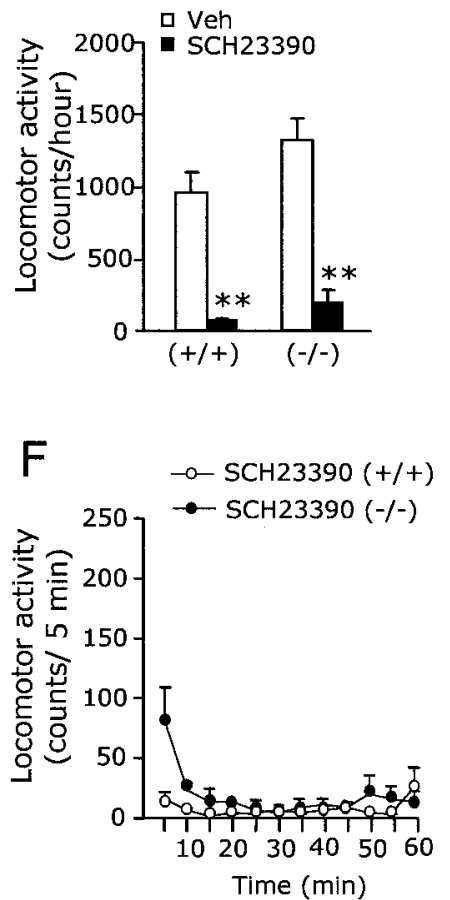

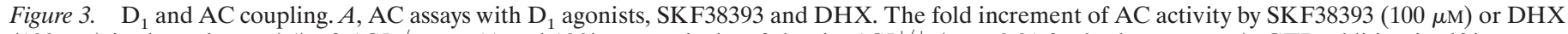

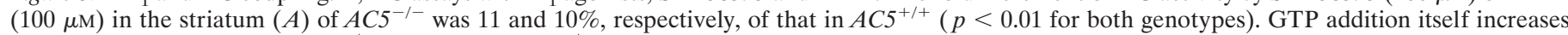

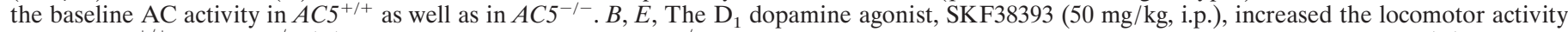

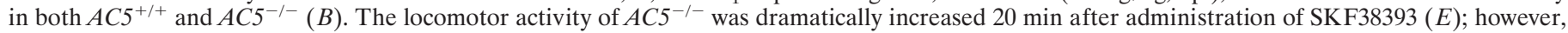

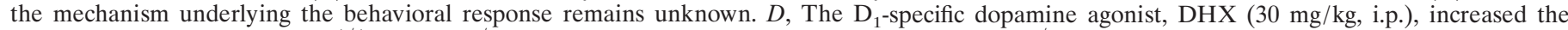

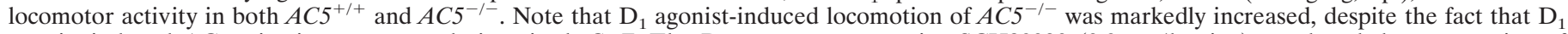

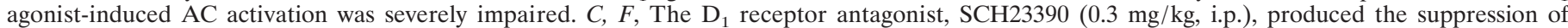

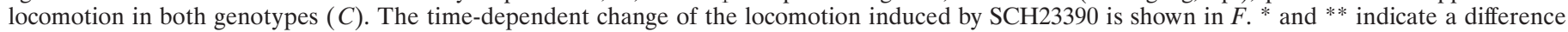
between two groups at $p<0.05$ and $p<0.01$, respectively. Base, Baseline; Veh, vehicle.

We examined whether the severe loss of the $\mathrm{A}_{2 \mathrm{~A}}$ agoniststimulated AC activity in the striatum of $A C 5^{-1-}$ could result in impaired behavior in response to $\mathrm{A}_{2 \mathrm{~A}}$ agonist treatment. Administration of the $\mathrm{A}_{2 \mathrm{~A}}$ agonist CGS21680 (0.5 mg/ $\mathrm{kg}$, i.p.) induced akinesis broadly in $A C 5^{+/+}$. Similarly, administration of the same dose of CGS21680 produced a strong suppression of motor behaviors in $A C 5^{-1-}$ (Fig. $4 B, C$ ). The locomotor activity in the open field after administration of the nonselective adenosine receptor antagonist, caffeine $(15 \mathrm{mg} / \mathrm{kg}$, i.p.), was increased in $A C 5^{-/-}$as seen in $A C 5^{+/+}$(Fig. 4D). These results indicate that the typical $\mathrm{A}_{2 \mathrm{~A}}$ receptor-specific pharmacology was retained, at least in part, at behavioral levels in $A C 5^{-1-}$.

\section{Coupling of $D_{2}$ dopamine receptors and AC5}

A possibility of coupling between AC5 and $\mathrm{D}_{2}$ was investigated. Because $\mathrm{D}_{2}$ dopamine receptors are negatively coupled to $\mathrm{AC}$ via $G_{\alpha i}$ protein, the effect of $D_{2}$ activation on AC activity can be measured clearly when $D_{2}$ is coactivated together with $D_{1}$ or other $\mathrm{G}_{\alpha \mathrm{s}}$-coupled receptors. Indeed, in the striatum of $A C 5^{+/+}$, $\mathrm{D}_{2}$ activation by quinpirole, a $\mathrm{D}_{2}$ agonist, suppressed the $\mathrm{D}_{1}$ agonist DHX $(0.5 \mu \mathrm{M})$-stimulated AC activity in a dosedependent manner, as was reported previously (Mottola et al., 1992). However, $D_{2}$ activation by quinpirole even at high doses failed to inhibit the DHX-stimulated AC activity in $A C 5^{-1-}$ (Fig. $5 A$ ). Similarly, the $\mathrm{D} 2$ agonist quinpirole did not produce any inhibitory effects on the AC activation induced by the neuropeptide VIP $(1 \mu \mathrm{M})$ or the $\mathrm{A}_{2 \mathrm{~A}} \mathrm{R}$ agonist, CGS21680 $(0.1 \mu \mathrm{M})$ in
$A C 5^{-/-}$(Fig. 5B,C). More decisively, the inhibitory effect of $\mathrm{D}_{2}$ activation on the forskolin $(0.1 \mu \mathrm{M})$-stimulated AC activity, unlike that in $A C 5^{+/+}$, was totally abolished in $A C 5^{-1-}$ (Fig. $5 D$ ). Together, these data consistently indicate that the $\mathrm{D}_{2}-\mathrm{G}_{\alpha \mathrm{i}}-\mathrm{AC}$ system is completely impaired in the striatum of $A C 5^{-/-}$.

\section{Coupling of other $\mathbf{G}_{\alpha \mathrm{i}}$-coupled receptors and AC5}

We explored whether other $G_{\alpha \mathrm{i}}$-coupled receptors also strictly require AC5. The receptors that are expressed abundantly in the striatum and negatively coupled to $A C$ through $G_{\alpha i}$ protein include muscarinic acetylcholine receptors $\mathrm{M}_{4}$ and $\mathrm{M}_{2}$ (Weiner et al., 1990; Gomeza et al., 1999). Biochemical assessment indicated that in the striatum of $A C 5^{+/+}$, the forskolin-stimulated $\mathrm{AC}$ activity was inhibited in a dose-dependent manner by oxotremorine, an agonist for muscarinic acetylcholine receptors. The forskolin-induced $\mathrm{AC}$ activity in the striatum of $A C 5^{-1-}$ was notably suppressed by oxotremorine, although the oxotremorineinduced inhibition appeared to be partially defective (Fig. 6A). In the frontal cortex of cerebrum in $A C 5^{-1-}$, the forskolininduced $\mathrm{AC}$ activation was also suppressed by oxotremorine (Fig. $6 B)$. Although this study did not aim at differentiating the identity of the oxotremorine-activated receptors, the oxotremorineresponsive receptors in the striatum might be $\mathrm{M}_{4}$ or $\mathrm{M}_{2}$ (Gomeza et al., 1999). Therefore, despite the fact that $>80 \%$ of forskolinstimulated AC activity was abolished and the $\mathrm{D}_{2}-\mathrm{G}_{\alpha \mathrm{i}}-\mathrm{AC}$ system was completely defective in the striatum of $A C 5^{-/-}$, at least a part 

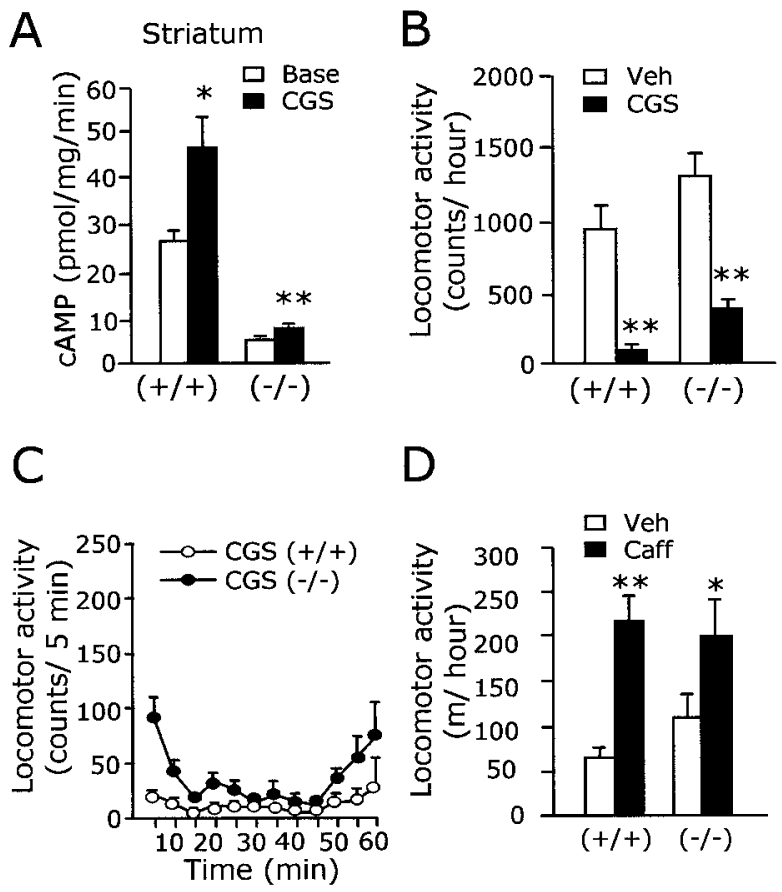

Figure 4. $\quad \mathrm{A}_{2 \mathrm{~A}}$ and $\mathrm{AC5}$ coupling. $A$, The $\mathrm{A}_{2 \mathrm{~A}}$ adenosine receptor agonist, CGS21680 $(10 \mu \mathrm{M})$, induced an increase of AC activity in the striatum of $A C 5^{+/+}$and $A C 5^{-1-}$. The CGS21680-induced increment of AC activity in $A C 5^{-1-}$ was $16 \%$ of that in wild-type littermates. $B, C$, The $\mathrm{A}_{2 \mathrm{~A}}$ agonist CGS21680 (0.5 $\mathrm{mg} / \mathrm{kg}$, i.p.) produced the suppression of locomotion in both $A C 5^{+/+}$and $A C 5^{-/-}(B)$. The time-dependent change of locomotion induced by CSG21680 is shown in C. D, Administration of caffeine $\left(15 \mathrm{mg} / \mathrm{kg}\right.$, i.p.) increased the locomotion of both $A C 5^{+/+}$and $A C 5^{-1-}$ mice. * and $* *$ indicate a difference between two groups at $p<$ 0.05 and $p<0.01$, respectively. Base, Baseline; CGS, CGS21680; Veh, vehicle; Caff, caffeine.

of the machinery of the $\mathrm{M}_{4}-\mathrm{G}_{\alpha \mathrm{i}}-\mathrm{AC}$ and $\mathrm{M}_{2}-\mathrm{G}_{\alpha \mathrm{i}}-\mathrm{AC}$ system in the striatum of $A C 5^{-/-}$appeared to be functional.

\section{$D_{1}$ and $D_{2}$ receptor densities and other gene expression}

To test the possibility that the biochemical deficit of the $\mathrm{D}_{2}-$ $\mathrm{G}_{\alpha \mathrm{i}}-\mathrm{AC}$ system is caused indirectly by the severe reduction of $\mathrm{D}_{2}$ expression in $\mathrm{AC5}^{-/-}$, we measured the dopamine receptor density in the striatum. The receptor binding study with $\mathrm{D}_{2}$ antagonist ${ }^{3} \mathrm{H}$-spiperone revealed no significant difference in $\mathrm{D}_{2}$ density between $A C 5^{-/-}$and $A C 5^{+/+}\left(B_{\max }\right.$ was $1.47 \pm 0.10(+/+)$ and $1.25 \pm 0.09(-/-) \mathrm{pmol} / \mathrm{mg}$ protein; $p>0.05)$. Consistently, the receptor binding study to brain tissue sections with another $\mathrm{D}_{2}$ ligand, ${ }^{125}$ I-sulpiride, indicated that the $\mathrm{D}_{2}$ receptor density in the brain of $A C 5^{-/-}$was comparable to that in wild-type littermates (data not shown). We observed that $\mathrm{D}_{1}$ density also was unchanged (Table 1). In addition, the expressions of $\mathrm{G}_{\alpha \mathrm{s}}, \mathrm{G}_{\alpha \mathrm{i}}$, $\mathrm{G}_{\alpha \mathrm{o}}$, and $\mathrm{G}_{\alpha \mathrm{z}}$ proteins and of the $\mathrm{PKA}_{\alpha}$ catalytic subunit and PKA regulatory subunits, $\mathrm{RI}$ and $\mathrm{RII}_{\alpha}$, in the striatum of $A C 5^{-/-}$ were unchanged (data not shown). Hence, the impairment of the $\mathrm{D}_{2}-\mathrm{G}_{\alpha \mathrm{i}}-\mathrm{AC}$ system in $A C 5^{-/-}$may be explained not by the reduced expression of $D_{2}$ or $G_{\alpha i}$ and $G_{\alpha o}$ or the increased expression of $D_{1}$, but by the total deficit of the $D_{2}-G_{\alpha i}-A C 5$ signaling in the striatal neurons.

We examined potential compensatory changes in the expression of genes for substance $\mathrm{P}$, dynorphin, neuropeptide $\mathrm{Y}$, enkephalin, tyrosine hydroxylase, GAD, and parvalbumin. Light microscopic examination of brain sections stained with antibody
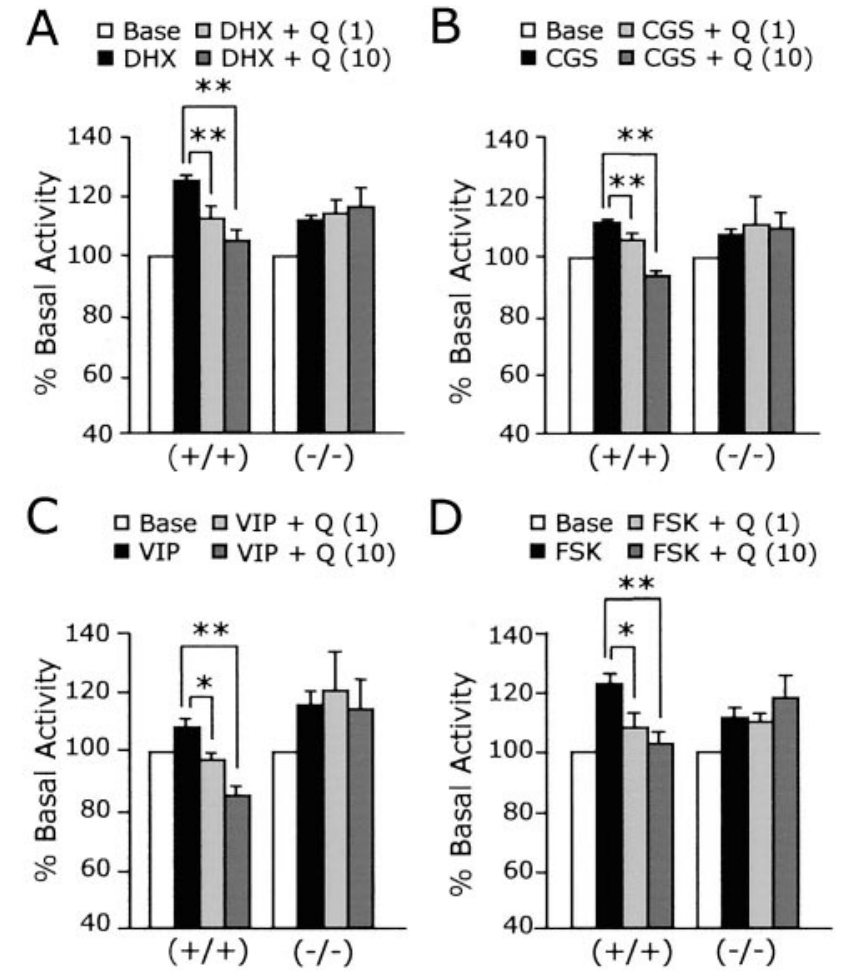

Figure 5. $\quad \mathrm{D}_{2}$ and $\mathrm{AC} 5$ coupling. $A$, The $\mathrm{D}_{1}$ agonist $\mathrm{DHX}(0.5 \mu \mathrm{M})$ induced AC activation in $A C 5^{+/+}$was suppressed in a dose-dependent manner by quinpirole, but not in $A C 5^{-1-} . Q(1)$ and $Q(10)$ denote, respectively, 1 and $10 \mu \mathrm{M}$ of quinpirole. Base, Baseline. $B-D$, The AC activity stimulated by $\mathrm{A}_{2 \mathrm{~A}}$ agonist CGS21680 $(0.1 \mu \mathrm{M})(B)$, neuropeptide VIP (1 $\mu \mathrm{M})(C)$, or forskolin $(0.1 \mu \mathrm{M})(D)$ was suppressed in a dose-dependent manner by quinpirole in $A C 5^{+/+}$but not in $A C 5^{-1-}$. The concentrations of DHX $(0.5 \mu \mathrm{M})$, CGS21680 $(0.1 \mu \mathrm{M})$, VIP $(1 \mu \mathrm{M})$, and forskolin $(0.1$ $\mu \mathrm{M})$ for $B-D$ were chosen on the basis of preliminary experiments, because they produced $\sim 110-130 \%$ of AC activation of the baseline control, which was also applied for the assay of muscarinic acetylcholine receptor activation in Figure $6 .{ }^{*}$ and $* *$ indicate a difference between two groups at $p<0.05$ and $p<0.01$, respectively.

for each of those showed no obvious change in the expression of these genes in the brain of $A C 5^{-1-}$ (data not shown). The expression of striatal peptides, for example, substance $\mathrm{P}$, dynorphin, neuropeptide Y, and enkephalin, was known to be influenced by the activity of $\mathrm{D}_{1}$ and $\mathrm{D}_{2}$ receptors. In particular, the expression of dynorphin was greatly reduced in $D_{1}{ }^{-/-}$, and the expression of GAD and enkephalin was significantly increased in $D_{2}^{--}$(Xu et al., 1994; Baik et al., 1995). However, the expression of dynorphin and enkephalin in the brain of $A C 5^{-/-}$mice was not altered. These results may suggest that AC5 is the principal AC but not the sole signaling effector for D1 and D2 receptors.

\section{Responses to the antipsychotic drugs sulpiride, haloperidol, and clozapine}

We investigated whether the biochemical deficit of the $D_{2}-$ $\mathrm{G}_{\alpha \mathrm{i}}-\mathrm{AC}$ system could be manifested with altered responses to $\mathrm{D}_{2}$ antagonists at behavioral levels. Administration of the $\mathrm{D}_{2}$ antagonist, sulpiride (50 mg/kg, i.p.), produced severe immobilization of wild-type littermates over the course of the monitoring period. In contrast, the same dose of the drug did not elicit such suppression in $A C 5^{-1-}$ animals (Fig. 7A,B). These data are consistent with the notion that AC5 is a crucial component for the $\mathrm{D}_{2}$ receptor signaling in striatal neurons. 

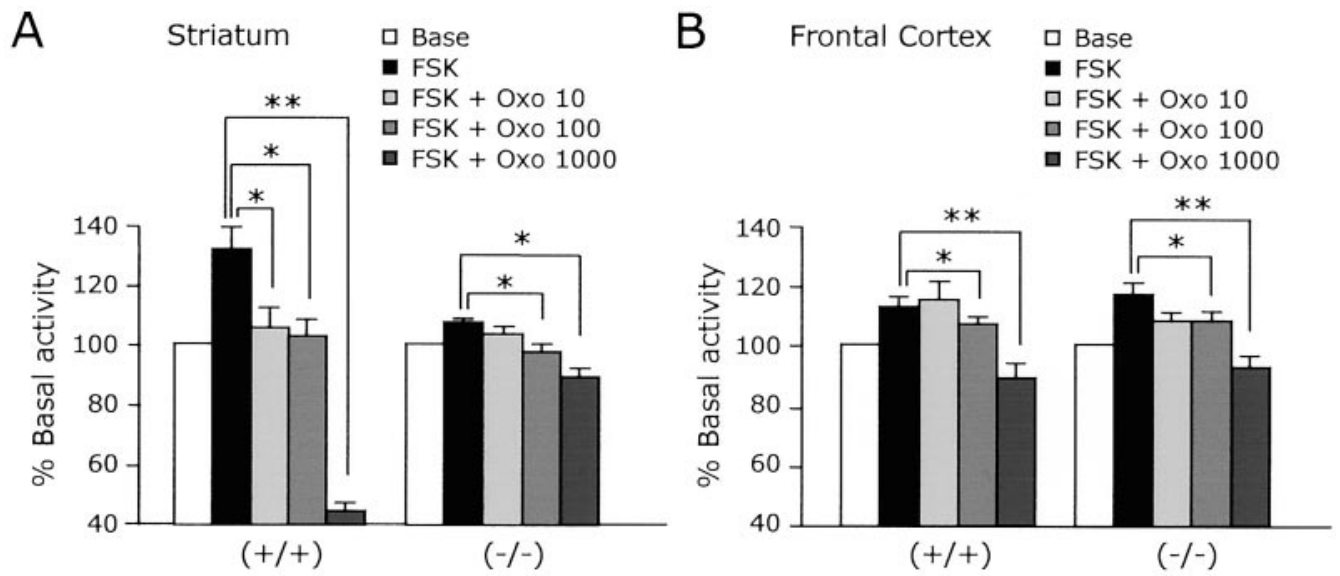

Figure 6. A functional muscarinic acetylcholine receptor system is present in the striatum of $A C 5^{-1-} . A, B$, Oxotremorine $(O x o)$, an agonist for muscarinic acetylcholine receptors, suppressed the forskolin $(0.1 \mu \mathrm{M})$-stimulated AC activity, in a dose-dependent manner, in the striatum $(A)$ and frontal cortex $(B)$ of both $A C 5^{+/+}$and $A C 5^{-1-}$. The muscarinic acetylcholine receptors that are negatively coupled to AC and expressed abundantly in the striatum include M4 and M2 receptors. The amount of AC activity suppressed strongly in $A C 5^{+/+}$by a high dose of oxo $(1,000 \mu \mathrm{M})$ appears to include the contribution of the GTP-stimulated AC activity as well as the forskolin-stimulated AC activity. * and ** indicate a difference between two groups at $p<0.05$ and $p<0.01$, respectively. Base, Baseline; FSK, forskolin. Oxo 10, Oxo 100, and Oxo 1000 were, respectively, 10, 100, and 1,000 $\mu$ M of oxotremorine.

\begin{tabular}{|c|c|c|c|c|}
\hline & \multicolumn{2}{|c|}{$\begin{array}{l}{ }^{3} \mathrm{H}-\mathrm{SCH} 23390 \\
\text { (D } \mathrm{D}_{1} \text { class receptors) }\end{array}$} & \multicolumn{2}{|c|}{$\begin{array}{l}{ }^{3} \mathrm{H} \text {-spiperone } \\
\left(\mathrm{D}_{2} \text { class receptors }\right)\end{array}$} \\
\hline & $B_{\max }$ & $K_{\mathrm{d}}$ & $B_{\max }$ & $K_{\mathrm{d}}$ \\
\hline$+/+$ & $2.16 \pm 0.30$ & $0.55 \pm 0.13$ & $1.47 \pm 0.10$ & $0.38 \pm 0.05$ \\
\hline$-1-$ & $2.22 \pm 0.28$ & $0.61 \pm 0.18$ & $1.25 \pm 0.09$ & $0.28 \pm 0.06$ \\
\hline
\end{tabular}

Values (mean \pm SEM) were the receptor density $\left(B_{\max }\right.$, picomoles per milligram protein) of $\mathrm{D}_{1}$ or $\mathrm{D}_{2}$ receptors, and the receptor affinity $\left(K_{\mathrm{d}}\right.$, nanomolar) for each ligand. The data were from four to five independent measurements with duplicates at each. The $\mathrm{D}_{1}$ or $\mathrm{D}_{2}$ dopamine receptor density and receptor affinity were not significantly different in both genotypes $\left(p>0.05\right.$ for both $B_{\max }$ and $\left.K_{\mathrm{d}}\right)$.

We further examined the effect of haloperidol, a typical antipsychotic drug the primary target of which is $\mathrm{D}_{2}$ (Seeman and Van Tol, 1994; Blin, 1999). Haloperidol administration (0.3-3 $\mathrm{mg} / \mathrm{kg}$, i.p.) quickly led to the immobilization of wild-type littermates for hours of observation. On the contrary, $A C 5^{-1-}$ animals that received the same doses of haloperidol displayed no sign of behavioral suppression but instead showed hyperactive locomotion (Fig. $7 C, D$ ). Consistently, as opposed to that in $A C 5^{+/+}$, administration of haloperidol ( $3 \mathrm{mg} / \mathrm{kg}$, i.p.) did not lead $A C 5^{-/-}$ animals to catalepsy (Fig. 7E). Thus, despite the presence of other ACs in the striatum, and potential non-AC effectors such as ion channels (Cai et al., 2000; Sidhu and Niznik, 2000), the neuroleptic effects of haloperidol were totally eliminated in $\mathrm{AC5}^{-1-}$. These results indicate that AC5 acts as an indispensable signaling route for the typical neuroleptic effects of haloperidol.

Similar to that for haloperidol, $A C 5^{-1-}$ mice were also hyperactive in response to clozapine, an atypical antipsychotic drug (Fig. $7 F$ ). After administration of clozapine, the locomotor activity of wild-type littermates was suppressed in a dose-dependent manner, whereas the locomotion of $\mathrm{AC5}^{-1-}$ marked consistently high scores in the same doses tested (Fig. $7 F$ ). These data suggest that AC5 is an important component for the neuroleptic action of clozapine, regardless of the fact that the behavioral response to clozapine in the open field test was slightly different from that of haloperidol.

\section{The increased locomotion by haloperidol or clozapine was antagonized by $D_{1}$ antagonist}

Because a list of reports indicated that haloperidol has a property to induce dopamine release (Di Chiara et al., 1977; Pehek, 1999; Westerink et al., 2001), we tested the possibility that the paradoxical haloperidol-induced increase of locomotion in $A C 5^{-1-}$ was related to the increased activation of dopamine receptors. First, we determined that the dose of 0.03 or $0.3 \mathrm{mg} / \mathrm{kg}$ of $\mathrm{D}_{1}$ antagonist SCH23390 (i.p.) produced, respectively, intermediate or almost complete suppression of locomotion of normal mice in the open field test (data not shown). In $\mathrm{AC5}^{-1-}$, the enhancement of locomotion by haloperidol $(0.3 \mathrm{mg} / \mathrm{kg}$, i.p.) was repressed intermediately by $0.03 \mathrm{mg} / \mathrm{kg}$ (i.p.) of SCH 23390 and completely by 0.3 $\mathrm{mg} / \mathrm{kg}$ (i.p.) of SCH23390. The total distance traveled for the given period reached the level of the SCH23390 treatment alone (Fig. 8A). Furthermore, the enhanced locomotion by clozapine (0.6 mg/kg, i.p.) was also antagonized intermediately by 0.03 $\mathrm{mg} / \mathrm{kg}$ (i.p.) of SCH 23390 and completely by $0.3 \mathrm{mg} / \mathrm{kg}$ (i.p.) of $\mathrm{SCH} 23390$ (Fig. 8B). These results suggest that the enhanced locomotion of $A C 5^{-1-}$ in response to haloperidol and clozapine resulted from the increased activation of $\mathrm{SCH} 23390$-sensitive $\mathrm{D}_{1}$ class dopamine receptors.

\section{DISCUSSION}

\section{Roles of AC5 in $D_{2}$ receptor function}

Targeted disruption of the $A C 5$ gene produced the complete elimination of $A C 5$ expression in the brain, which made it possible to delineate the indispensable role of AC5 downstream $\mathrm{D}_{2}$ receptors. The typical inhibitory effect of $\mathrm{D}_{2}$ activation on $\mathrm{D}_{1}$ agonist-, $\mathrm{A}_{2 \mathrm{~A}}$ agonist-, and forskolin-stimulated AC activity was completely abolished in $A C 5^{-/-}$(Fig. 5). It appeared that other types of ACs present in the striatum were not responsive to $\mathrm{D}_{2}$ receptor activation. In accordance with this notion, administration of the $\mathrm{D}_{2}$ antagonists, haloperidol and sulpiride, did not produce the typical neuroleptic effects in $A C 5^{-1-}$ animals, unlike those in $A C 5^{+/+}$(Fig. 7A-D). Together, these results are consistent with the conclusion that AC5 is the physiologically relevant $\mathrm{AC}$ for $\mathrm{D}_{2}$ receptors and that AC5 is a necessary route for the neuroleptic action of these antipsychotic drugs. 
A
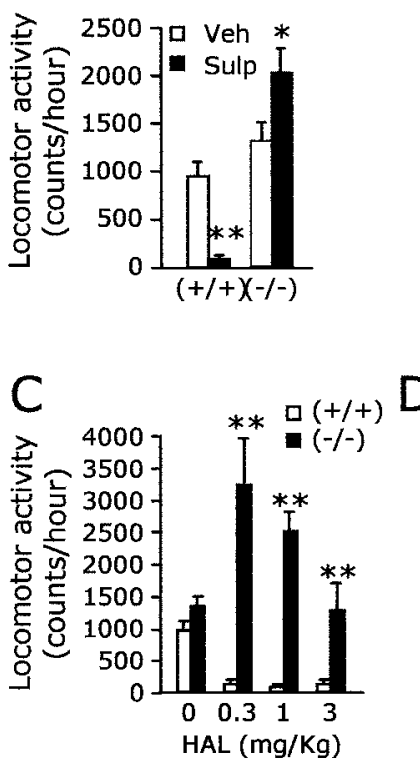

$E$

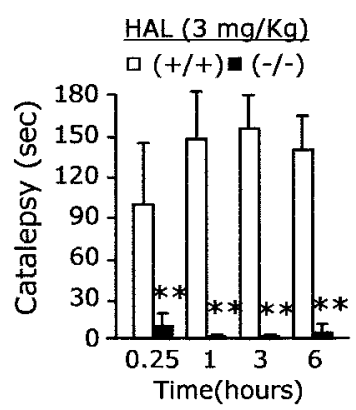

B
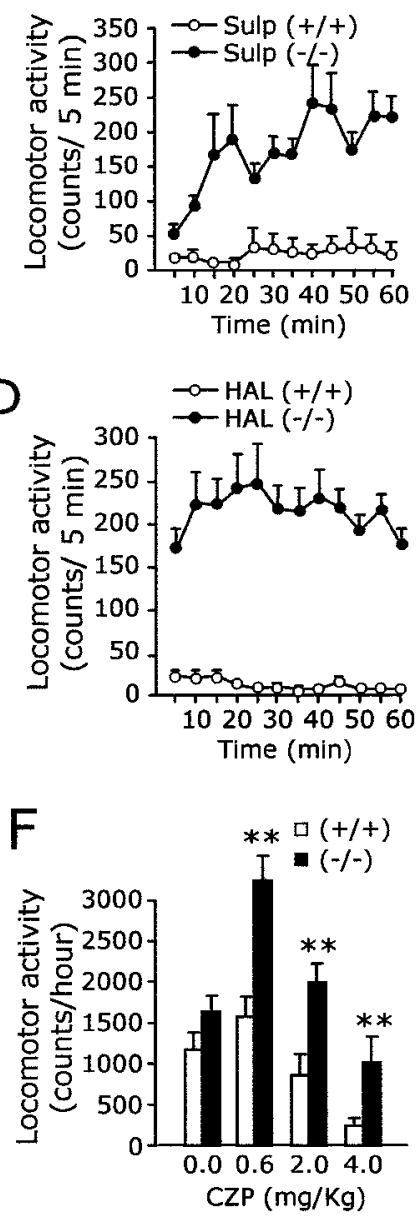

Figure 7. Loss of neuroleptic responsiveness to antipsychotic drugs in $A C 5^{-/-}$mice. $A$, The $\mathrm{D}_{2}$ antagonist, sulpiride (50 mg/kg, i.p.), induced a decrease of motor activity in $A C 5^{+/+}$but produced a marked enhancement of locomotion in $A C 5^{-/-}(p<0.01$ for $+/+$, and $p<0.05$ for $-/-)$. $B$, The locomotion of $A C 5^{-1-}$ was gradually accelerated after administration of sulpiride. $C$, Haloperidol induced akinesis broadly in wild-type littermates but did not elicit such behavioral suppression in mutant animals. Note the dramatic enhancement of locomotion in $A C 5^{-1-}$ at lower doses of haloperidol. $D$, Time-dependent changes of locomotion induced by $1 \mathrm{mg} / \mathrm{kg}$ of haloperidol are presented. $E$, As opposed to that in $A C 5^{+/+}$, cataleptic response was induced by haloperidol ( $3 \mathrm{mg} / \mathrm{kg}$, i.p.) in $A C 5^{-/-}$. For convenience, $180 \mathrm{sec}$ of cutoff time was set for all cases that lasted $>180$ sec. $F$, Clozapine produced a substantial decrease of locomotion in both mutant and wild-type littermates in a dose-dependent manner, but its depression effect on the motor activity was markedly diminished in $A C 5^{-1-}$. Note the sharply increased locomotion of $A C 5^{-1-}$ by a low dose $(0.6 \mathrm{mg} / \mathrm{kg})$ of clozapine. ${ }^{*}$ and $* *$ indicate a difference between two groups at $p<0.05$ and $p<0.01$, respectively. Veh, Vehicle; Sulp, sulpiride; $H A L$, haloperidol; $C Z P$, clozapine.

It is unlikely, however, that the absence of the neuroleptic effects and the total impairment of the $D_{2}-G_{\alpha i}-A C$ system in $A C 5^{-/-}$were produced indirectly by the reduced expression of the $\mathrm{G}_{\alpha \mathrm{i}}$ system or the $\mathrm{D}_{2}$ receptor itself. First, it was observed that the forskolin-induced AC activation in $A C 5^{-/-}$, although it was low, was suppressed by oxotremorine, an agonist for muscarinic acetylcholine receptors (Fig. 6). This result indicates the presence of the functional $\mathrm{G}_{\alpha \mathrm{i}}$-coupled receptor system in $A C 5^{-/-}$. Furthermore, the expression level of $\mathrm{G}_{\alpha \mathrm{i}}$ in the striatum of $A C 5^{-/-}$ was comparable to that of $A C 5^{+/+}$(data not shown). Therefore, the complete absence of $\mathrm{D}_{2}$-mediated $\mathrm{AC}$ inhibition in $A C 5^{-/-}$
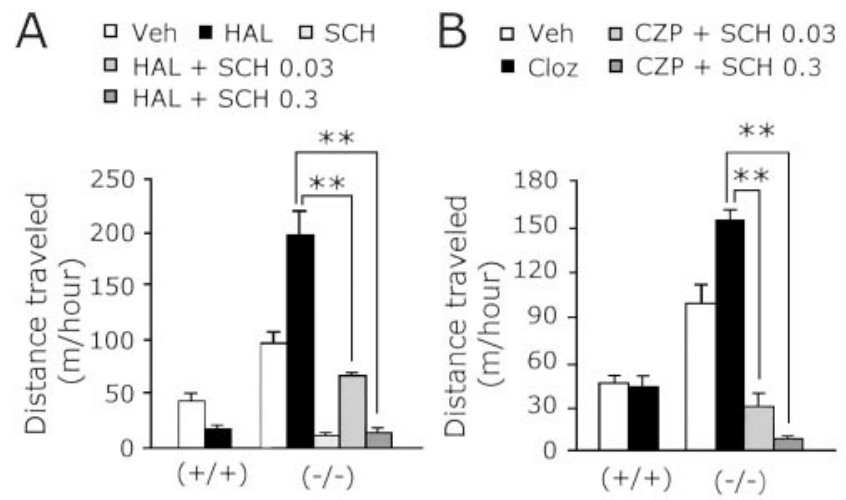

Figure 8. The increased locomotion by haloperidol or clozapine was antagonized by $\mathrm{D}_{1}$ antagonist. $A$, The enhancement of locomotion by haloperidol $(0.3 \mathrm{mg} / \mathrm{kg}$, i.p.) was repressed in a dose-dependent manner by $\mathrm{D}_{1}$ antagonist $\mathrm{SCH} 23390$. $B$, The enhanced locomotion by clozapine $(0.6 \mathrm{mg} / \mathrm{kg}$, i.p.) was also antagonized in a dose-dependent manner by $\mathrm{SCH} 23390$. ${ }^{* *}$ indicates a difference between two groups at $p<0.01$. $H A L$, Haloperidol; SCH, SCH23390; $S C H 0.03,0.03$ mg/kg SCH; $S C H$ $0.3,0.3 \mathrm{mg} / \mathrm{kg} \mathrm{SCH}$.

cannot be attributed to the general property of receptors that are negatively coupled to $\mathrm{AC}$ or to the low levels of forskolinstimulated AC activity in the striatum of $A C 5^{-1-}$ (Fig. 2A). Second, receptor-binding studies with ${ }^{3} \mathrm{H}$-spiperone revealed that the $\mathrm{D}_{2}$ receptor density was slightly reduced in $A C 5^{-/-}$, which was insignificant (Table 1). Given that heterozygous mice deficient for dopamine receptor $\mathrm{D}_{2}\left(D_{2}{ }^{+-}\right)$that carry $\sim 50 \%$ of $\mathrm{D}_{2}$ receptors were notably suppressed by $\mathrm{D}_{2}$ antagonist in the open field test (Kelly et al., 1998), the lack of neuroleptic effects in $A C 5^{-1-}$ cannot be explained by the loss of $\mathrm{D}_{2}$ receptors in the striatum. It remains unknown at present whether the total impairment of the $\mathrm{D}_{2}-\mathrm{AC}$ system in the striatum of $A C 5^{-1-}$, even in the presence of other ACs and the $\mathrm{G}_{\alpha \mathrm{i}}$ protein system, was caused by the failure of colocalization of $\mathrm{D}_{2}$ receptor with other ACs in the same neurons or the inability of $\mathrm{D}_{2}$ to pair with other ACs.

Interestingly, the neuroleptic drugs, sulpiride, haloperidol, and clozapine, produced a markedly enhanced locomotion in $\mathrm{AC}^{-/-}$, especially at low doses (Fig. 7). Although no direct evidence is available at present, these results are tempting us to speculate that inhibition by these drugs of presynaptic $\mathrm{D}_{2}$, or $\mathrm{D}_{2 \mathrm{~S}}$ as implied by Usiello et al. (2000), might result in an increase of dopamine release in the striatum, which in turn produces the enhanced locomotion in $\mathrm{AC5}^{-1-}$. This hypothesis is consistent with our finding that the paradoxical enhancement of locomotion by haloperidol ( $0.3 \mathrm{mg} / \mathrm{kg}$, i.p.) or clozapine $(0.6 \mathrm{mg} / \mathrm{kg}$, i.p.) was antagonized by $\mathrm{SCH} 23390(0.3 \mathrm{mg} / \mathrm{kg}$, i.p.) as shown in Figure 8, but not by the $\mathrm{A}_{2 \mathrm{~A}}$ agonist, CGS23390, at the dose that produced the complete immobilization (K.-W. Lee and P.-L. Han, unpublished observations). So, $\mathrm{D}_{1}$ receptor activity in postsynaptic neurons seems to be important for the $\mathrm{D}_{2}$ antagonist-induced increase of locomotion in $A C 5^{-1-}$. This speculation agreed with the fact that $\mathrm{D}_{1}$-dependent pharmaco-behaviors were retained in $A C 5^{-1-}$ (Fig. 3). However, given that dopamine receptors are expressed at low levels in many brain regions, including frontal cortex, we do not exclude the possibility that AC5-uncoupled $\mathrm{D}_{2}$ receptors in striatal or extrastriatal regions contribute the neuroleptic-induced enhanced locomotion in $\mathrm{AC} 5^{-/-}$. Nonetheless, the remarkable increase of locomotion by haloperidol or clozapine in $A C 5^{-1-}$ is consistent with the notion that both haloperidol and clozapine had a property of increasing locomo- 
tion in the open field test that was produced in part by a common mechanism that involved the increased release of dopamine, as was suggested previously (Di Chiara et al., 1977; Pehek, 1999; Westerink et al., 2001).

\section{Issues of $D_{2}-A C 5$ coupling}

Colocalization of $\mathrm{AC5}$ and $\mathrm{D}_{2}$ receptors in striatal neurons (Mons and Cooper, 1994) and the coupling between $\mathrm{D}_{2}$ and AC5 as demonstrated in this study raised the question of whether $A C 5^{-/-}$mice were the phenocopy of $D_{2}^{-1-}$ (Baik et al., 1995; Jung et al., 1999; Wang et al., 2000). The phenotype of $A C 5^{-/-}$ mice has a similarity to that of $D_{2}^{-1-}$. For example, $A C 5^{-1-}$ mice were not driven into catalepsy by haloperidol (Fig. $7 E$ ), as were $D_{2}{ }^{-1-}$ and $D_{2 L}{ }^{-1-}$ (Kelly et al., 1998; Usiello et al., 2000).

It was somewhat unique to $A C 5^{-1-}$, however, that the locomotion was highly increased by haloperidol (Fig. 7). In addition, despite the complete deficit of $\mathrm{D}_{2}-\mathrm{G}_{\alpha \mathrm{i}}-\mathrm{AC}$ signaling in the striatum (Fig. 6), $A C 5^{-1-}$ mice did not show Parkinsonian-like phenotypes or the reduced spontaneous general motor activities displayed by $D_{2}^{-/-}$or $D_{2 L}{ }^{-/-}$mice (Baik et al., 1995; Jung et al., 1999; Wang et al., 2000). The preservation of spontaneous motor function in $A C 5^{-/-}$mice raises the possibility that the $\mathrm{D}_{2}-\mathrm{G}_{\alpha \mathrm{i}}{ }^{-}$ AC5 system, although it is normally required for transmitting the neuroleptic effects of antipsychotic drugs, comprises only a part of $\mathrm{D}_{2}$ signaling pathways. In fact, a list of reports indicates that $\mathrm{D}_{2}$ receptors are coupled to multiple types of $\mathrm{G}_{\alpha}$-proteins including $\mathrm{G}_{\alpha \mathrm{i}}, \mathrm{G}_{\alpha \mathrm{z}}$, and $\mathrm{G}_{\alpha \mathrm{O}}$, which in turn link to various effector systems (Cai et al., 2000; Sidhu and Niznik, 2000; Jiang et al., 2001). Given that the $\mathrm{D}_{2}-\mathrm{G}_{\alpha \mathrm{i}}-\mathrm{AC5}$ cascade was the major or essential signal route for neuroleptic drugs, the significance of $\mathrm{D}_{2}$ receptor signaling cascades should be evaluated in the physiological context.

Last, it may be worth noting that the loss of haloperidolinduced catalepsy was not limited to $A C 5^{-1-}$ or $D_{2}^{-1-}$. Mice lacking the $\mathrm{RII}_{\beta}$ subunit of protein kinase A (PKA) had a markedly reduced PKA activity in the striatum and showed no catalepsy in response to haloperidol (Adams et al., 1997). The complete absence of cataleptic responses to haloperidol in both $A C 5^{-1-}$ and $P K A-R I I \beta^{-1-}$ mice implies that an appropriate control of the cAMP pathway in the striatum is essential for the action of the neuroleptic haloperidol.

\section{Roles of $A C 5$ in $D_{1}$ receptor function}

A well established and long-lasting dogma in dopamine receptor biology is that $\mathrm{D}_{1}$ dopamine receptor activation leads to the stimulation of AC to produce distinct physiological and pharmacological responses (Kebabian and Calne, 1979; Creese et al., 1983; Seeman and Van Tol, 1994; Missale et al., 1998). In fact, the treatment of $\mathrm{D}_{1}$ agonists DHX or SKF38393 produced a marked enhancement of AC activity in $A C 5^{+/+}$. In $A C 5^{-/-}$, the DHX- or SKF38393-stimulated AC activity was significantly increased, although the maximal AC activity in the given condition reached $10-11 \%$ of that in wild-type littermates (Fig. $3 A$ ). These data are consistent with the view that AC5 is the primary, long-sought AC for $\mathrm{D}_{1}$ receptors (Kebabian and Calne, 1979; Creese et al., 1983) and that $D_{1}$ receptors use other ACs as well, thus using dual/ multiple AC systems in the striatum.

In $A C 5^{-1-}$, administration of the $\mathrm{D}_{1}$ agonist SKF38393 or DHX produced an increase of locomotion in the open field test (Fig. $3 B, D, E)$. In addition, administration of the $\mathrm{D}_{1}$ antagonist SCH23390 induced the depression of motor activity, which was similar to that in $A C 5^{+/+}$(Fig. $3 C, F$ ). Thus, the behavioral responses of $A C 5^{-/-}$mice apparently satisfy the pharmacological criteria of $\mathrm{D}_{1}$ receptor functions, despite the fact that $\mathrm{D}_{1}$ agonistinduced AC stimulation was severely impaired. Interestingly, the SKF38393- or DHX-induced locomotion in $A C 5^{-1-}$ was not intact but was double that of $A C 5^{+/+}$(Fig. $3 B, D$ ). This D1 agonist-induced amplified locomotion of $A C 5^{-1-}$ cannot be explained by a compensatory increase of $\mathrm{D}_{1}$ expression in the striatum, because $\mathrm{D}_{1}$ expression was not altered (Table 1). The $\mathrm{D}_{1}$ agonist-induced increase of the locomotion in $A C 5^{-1-}$ was produced in the absence of the $\mathrm{D}_{2}-\mathrm{G}_{\alpha \mathrm{i}}-\mathrm{AC5}$-mediated inhibitory tone. Hence, we are tempted to speculate that the enhanced locomotion by SKF38393 or DHX in normal mice is the outcome of the antagonistic interaction of $\mathrm{D}_{1}$ and $\mathrm{D}_{2}$.

Although the $\mathrm{D}_{1}$ agonist DHX or SKF38393 significantly increased AC activity in $A C 5^{-1-}$, how the $\mathrm{D}_{1}$ class-dependent pharmaco-behaviors (Fig. 3) were produced is not clear at present. It may be possible that the $\mathrm{D}_{1}$-dependent behaviors of $A C 5^{-1-}$ were produced by the residual AC system in the striatum (Fig. 2A). However, we do not exclude the possibility that the $\mathrm{D}_{1}$-dependent behavior of $A C 5^{-/-}$is related to the non-AC effector system, such as $\mathrm{D}_{1}$-coupled phospholipase $\mathrm{C}$ (Clifford et al., 1999), or $\mathrm{D}_{1}$ class receptors that do not rely on AC5 and are expressed in extrastriatal motor control regions in the brain. It is also possible that complex types of adaptations including altered expression of uncharacterized AC pathway components or developmental changes at a circuit level could produce the $\mathrm{D}_{1}$ dependent pharmaco-behaviors of $A C 5^{-1-}$ mutants. Nonetheless, our results indicate that although the behavioral responses controlled by D2 receptors seem to involve the AC5 pathway, the behavioral effects mediated by D1 receptors do not.

\section{Roles of AC5 in $A_{2 A}$ receptor function}

In the current study, we demonstrated that similar to that of $D_{1}$ receptors, $\mathrm{AC} 5$ is the major $\mathrm{AC}$ for $\mathrm{A}_{2 \mathrm{~A}}$ in the striatum, and $\mathrm{A}_{2 \mathrm{~A}}$ receptors can function, at least in part, independently of AC5. Thus, $A_{2 A}$ receptors use dual-multiple $\mathrm{AC}$ systems, for which AC5 is the principal AC for $A_{2 A}$ receptors (Fig. 4). Because AC5 is required for both $D_{2}$ and $A_{2 A}$ (Figs. 4, 5) and $D_{2}$ and $A_{2 A}$ receptors are colocalized in the same striatal neurons (Fink et al., 1992; Augood and Emson, 1994), the integrative mechanism of two receptor systems should take place at the level of AC5. This feature of the receptor-effector interaction indicates that the signaling pathways of $\mathrm{A}_{2 \mathrm{~A}}$ and $\mathrm{D}_{2}$ receptors in the striatal neurons constitute a network of a literally unseparable system. Given that in wild-type mice, $\mathrm{D}_{1}$-stimulated $\mathrm{AC}$ activity was inhibited by $\mathrm{D}_{2}$ activation (Fig. $5 A$ ), at least some of the $\mathrm{D}_{1}$ and $\mathrm{D}_{2}$ receptors appear to localize in a close proximity to each other in the same striatal neurons (Surmeier et al., 1996; Aizman et al., 2000). So, the unseparable signaling network could be extended to the interaction between $\mathrm{A}_{2 \mathrm{~A}}$ and $\mathrm{D}_{2}$ and $\mathrm{D}_{1}$ receptor systems, in which AC5 plays a key and common role.

\section{REFERENCES}

Adams MR, Brandon EP, Chartoff EH, Idzerda RL, Dorsa DM, McKnight GS (1997) Loss of haloperidol induced gene expression and catalepsy in protein kinase A-deficient mice. Proc Natl Acad Sci USA 94:12157-12161.

Aizman O, Brismar H, Uhlen P, Zettergren E, Levey AI, Forssberg H, Greengard P, Aperia A (2000) Anatomical and physiological evidence for D1 and D2 dopamine receptor colocalization in neostriatal neurons. Nat Neurosci 3:226-230.

Antoni FA, Palkovits M, Simpson J, Smith SM, Leitch AL, Rosie R, Fink G, Paterson JM (1998) $\mathrm{Ca}^{2+} /$ calcineurin-inhibited adenylyl cyclase, highly abundant in forebrain regions, is important for learning and memory. J Neurosci 18:9650-9661. 
Augood SJ, Emson PC (1994) Adenosine A2a receptor mRNA is expressed by enkephalin cells but not by somatostatin cells in rat striatum: a co-expression study. Brain Res Mol Brain Res 22:204-210.

Baik JH, Picetti R, Saiardi A, Thiriet G, Dierich A, Depaulis A, Le Meur M, Borrelli E (1995) Parkinsonian-like locomotor impairment in mice lacking dopamine D2 receptors. Nature 377:424-428.

Blin O (1999) A comparative review of new antipsychotics. Can J Psychiatry 44:235-244.

Buck J, Sinclair ML, Schapal L, Cann MJ, Levin LR (1999) Cytosolic adenylyl cyclase defines a unique signaling molecule in mammals. Proc Natl Acad Sci USA 96:79-84.

Cai G, Zhen X, Uryu K, Friedman E (2000) Activation of extracellular signal-regulated protein kinases is associated with a sensitized locomotor response to $\mathrm{D}(2)$ dopamine receptor stimulation in unilateral 6-hydroxydopamine-lesioned rats. J Neurosci 20:1849-1857.

Cali JJ, Zwaagstra JC, Mons N, Cooper DM, Krupinski J (1994) Type VIII adenylyl cyclase. A Ca ${ }^{2+} /$ calmodulin-stimulated enzyme expressed in discrete regions of rat brain. J Biol Chem 269:12190-12195.

Chabardes D, Imbert-Teboul M, Elalouf JM (1999) Functional properties of $\mathrm{Ca}^{2+}$-inhibitable type 5 and type 6 adenylyl cyclases and role of $\mathrm{Ca}^{2+}$ increase in the inhibition of intracellular cAMP content. Cell Signal 11:651-663.

Clifford JJ, Tighe O, Croke DT, Kinsella A, Sibley DR, Drago J, Waddington JL (1999) Conservation of behavioural topography to dopamine D1-like receptor agonists in mutant mice lacking the D1A receptor implicates a D1-like receptor not coupled to adenylyl cyclase. Neuroscience 93:1483-1489.

Creese I, Sibley DR, Hamblin MW, Leff SE (1983) The classification of dopamine receptors: relationship to radioligand binding. Annu Rev Neurosci 6:43-71.

Di Chiara G, Porceddu ML, Spano PF, Gessa GL (1977) Haloperidol increases and apomorphine decreases striatal dopamine metabolism after destruction of striatal dopamine-sensitive adenylate cyclase by kainic acid. Brain Res 130:374-382.

Dulawa SC, Grandy DK, Low MJ, Paulus MP, Geyer MA (1999) Dopamine D4 receptor-knock-out mice exhibit reduced exploration of novel stimuli. J Neurosci 19:9550-9556.

Ebadi M, Srinivasan SK (1995) Pathogenesis, prevention, and treatment of neuroleptic-induced movement disorders. Pharmacol Rev 47:575-604.

Ferre S, Fredholm BB, Morelli M, Popoli P, Fuxe K (1997) Adenosinedopamine receptor-receptor interactions as an integrative mechanism in the basal ganglia. Trends Neurosci 20:482-487.

Fink JS, Weaver DR, Rivkees SA, Peterfreund RA, Pollack AE, Adler EM, Reppert SM (1992) Molecular cloning of the rat A2 adenosine receptor: selective co-expression with D2 dopamine receptors in rat striatum. Brain Res Mol Brain Res 14:186-195.

Glatt CE, Snyder SH (1993) Cloning and expression of an adenylyl cyclase localized to the corpus striatum. Nature 361:536-538.

Gomeza J, Zhang L, Kostenis E, Felder C, Bymaster F, Brodkin J, Shannon H, Xia B, Deng C, Wess J (1999) Enhancement of D1 dopamine receptor-mediated locomotor stimulation in M(4) muscarinic acetylcholine receptor knockout mice. Proc Natl Acad Sci USA 96:10483-10488.

Hanoune J, Defer N (2001) Regulation and role of adenylyl cyclase isoforms. Annu Rev Pharmacol Toxicol 41:145-174.

Jang C, Park Y, Tanaka S, Ma T, Loh HH, Ho IK (2000) Involvement of $\mathrm{mu}$-opioid receptors in potentiation of apomorphine-induced climbing behavior by morphine: studies using mu-opioid receptor gene knockout mice. Brain Res Mol Brain Res 78:204-206.

Jiang M, Spicher K, Boulay G, Wang Y, Birnbaumer L (2001) Most central nervous system D2 dopamine receptors are coupled to their effectors by Go. Proc Natl Acad Sci USA 98:3577-3582.

Joyner AL (1993) Gene targeting. A practical approach. New York: Oxford UP.

Jung MY, Skryabin BV, Arai M, Abbondanzo S, Fu D, Brosius J, Robakis NK, Polites HG, Pintar JE, Schmauss C (1999) Potentiation of the D2 mutant motor phenotype in mice lacking dopamine D2 and D3 receptors. Neuroscience 91:911-924.

Kebabian JW, Calne DB (1979) Multiple receptors for dopamine. Nature 277:93-96.

Kelly MA, Rubinstein M, Phillips TJ, Lessov CN, Burkhart-Kasch S, Zhang G, Bunzow JR, Fang Y, Gerhardt GA, Grandy DK, Low MJ (1998) Locomotor activity in D2 dopamine receptor-deficient mice is determined by gene dosage, genetic background, and developmental adaptations. J Neurosci 18:3470-3479.

Kim D, Jun KS, Lee SB, Kang NG, Min DS, Kim YH, Ryu SH, Suh PG,
Shin HS (1997) Phospholipase C isozymes selectively couple to specific neurotransmitter receptors. Nature 389:290-293.

Kim IJ, Lee KW, Park BY, Lee JK, Park J, Choi IY, Eom SJ, Chang TS, Kim MJ, Yeom YI, Chang SK, Lee YD, Choi EJ, Han PL (1999) Molecular cloning of multiple splicing variants of JIP-1 preferentially expressed in brain. J Neurochem 72:1335-1343.

Lane-Ladd SB, Pineda J, Boundy VA, Pfeuffer T, Krupinski J, Aghajanian GK, Nestler EJ (1997) CREB (cAMP response element-binding protein) in the locus coeruleus: biochemical, physiological, and behavioral evidence for a role in opiate dependence. $\mathrm{J}$ Neurosci 17:7890-7901.

Lee JK, Park J, Lee YD, Lee SH, Han PL (1999) Distinct localization of SAPK isoforms in neurons of adult mouse brain implies multiple signaling modes of SAPK pathway. Brain Res Mol Brain Res 70:116-124.

Levey AI, Hersch SM, Rye DB, Sunahara RK, Niznik HB, Kitt CA, Price DL, Maggio R, Brann MR, Ciliax BJ (1993) Localization of D1 and D2 dopamine receptors in brain with subtype-specific antibodies. Proc Natl Acad Sci USA 90:8861-8865.

Liu FC, Wu GC, Hsieh ST, Lai HL, Wang HF, Wang TW, Chern Y (1998) Expression of type VI adenylyl cyclase in the central nervous system: implication for a potential regulator of multiple signals in different neurotransmitter systems. FEBS Lett 436:92-98.

Matsuoka I, Suzuki Y, Defer N, Nakanishi H, Hanoune J (1997) Differential expression of type I, II, and V adenylyl cyclase gene in the postnatal developing rat brain. J Neurochem 68:498-506.

Missale C, Nash SR, Robinson SW, Jaber M, Caron MG (1998) Dopamine receptors: from structure to function. Physiol Rev 78:189-225.

Mons N, Cooper DM (1994) Selective expression of one $\mathrm{Ca}^{2+}$ )inhibitable adenylyl cyclase in dopaminergically innervated rat brain regions. Brain Res Mol Brain Res 22:236-244.

Mons N, Yoshimura M, Ikeda H, Hoffman PL, Tabakoff B (1998) Immunological assessment of the distribution of type V II adenylyl cyclase in brain. Brain Res 788:251-261.

Moreau JL, Huber G (1999) Central adenosine A(2A) receptors: an overview. Brain Res Brain Res Rev 31:65-82.

Mottola DM, Brewster WK, Cook LL, Nichols DE, Mailman RB (1992) Dihydrexidine, a novel full efficacy D1 dopamine receptor agonist. J Pharmacol Exp Ther 262:383-393.

Olianas MC, Maullu C, Onali P (1997) Effects of clozapine on rat striatal muscarinic receptors coupled to inhibition of adenylyl cyclase activity and on the human cloned $\mathrm{m} 4$ receptor. Br J Pharmacol 122:401-408.

Onali P, Olianas MC, Gessa GL (1985) Characterization of dopamine receptors mediating inhibition of adenylate cyclase activity in rat striatum. Mol Pharmacol 28:138-145.

Pehek EA (1999) Comparison of effects of haloperidol administration on amphetamine-stimulated dopamine release in the rat medial prefrontal cortex and dorsal striatum. J Pharmacol Exp Ther 289:14-23.

Premont RT, Chen J, Ma HW, Ponnapalli M, Iyengar R (1992) Two members of a widely expressed subfamily of hormone-stimulated adenylyl cyclases. Proc Natl Acad Sci USA 89:9809-9813.

Seeman P, Van Tol HH (1994) Dopamine receptor pharmacology. Trends Pharmacol Sci 15:264-270.

Sidhu A, Niznik HB (2000) Coupling of dopamine receptor subtypes to multiple and diverse G proteins. Int J Dev Neurosci 18:669-677.

Surmeier DJ, Song WJ, Yan Z (1996) Coordinated expression of dopamine receptors in neostriatal medium spiny neurons. $J$ Neurosci 16:6579-6591.

Usiello A, Baik JH, Rouge-Pont F, Picetti R, Dierich A, LeMeur M, Piazza PV, Borrelli E (2000) Distinct functions of the two isoforms of dopamine D2 receptors. Nature 408:199-203.

Wang Y, Xu R, Sasaoka T, Tonegawa S, Kung MP, Sankoorikal EB (2000) Dopamine D2 long receptor-deficient mice display alterations in striatum-dependent functions. J Neurosci 20:8305-8314.

Weiner DM, Levey AI, Brann MR (1990) Expression of muscarinic acetylcholine and dopamine receptor mRNAs in rat basal ganglia. Proc Natl Acad Sci USA 87:7050-7054.

Westerink BH, Kawahara Y, De Boer P, Geels C, De Vries JB, Wikstrom HV, Van Kalkeren A, Van Vliet B, Kruse CG, Long SK (2001) Antipsychotic drugs classified by their effects on the release of dopamine and noradrenaline in the prefrontal cortex and striatum. Eur J Pharmacol 412:127-138.

Xu M, Hu XT, Cooper DC, Moratalla R, Graybiel AM, White FJ, Tonegawa S (1994) Elimination of cocaine-induced hyperactivity and dopamine-mediated neurophysiological effects in dopamine D1 receptor mutant mice. Cell 79:945-955. 